\title{
Characterization of the Burkholderia cenocepacia J2315 Surface-Exposed Immunoproteome
}

\author{
Sílvia A. Sousa ${ }^{1, *(\mathbb{C})}$, António M.M. Seixas ${ }^{1,+}+\mathbb{C}$, Manoj Mandal ${ }^{1,+}$, \\ Manuel J. Rodríguez-Ortega ${ }^{2}$ aD and Jorge H. Leitão ${ }^{1, *(D)}$ \\ 1 iBB-Institute for Bioengineering and Biosciences, 1049-001 Lisbon, Portugal; \\ antonio.seixas@tecnico.ulisboa.pt (A.M.M.S.); manoj2biomedical@gmail.com (M.M.) \\ 2 Departament of Biochemistry and Molecular Biology, Córdoba University, 14071 Córdoba, Spain; \\ mjrodriguez@uco.es \\ * Correspondence: sousasilvia@tecnico.ulisboa.pt (S.A.S.); jorgeleitao@tecnico.ulisboa.pt (J.H.L.); \\ Tel.: +351-2184-19986 (S.A.S.); +351-2184-17688 (J.H.L.) \\ + Both authors contributed equally to the work.
}

Received: 31 July 2020; Accepted: 3 September 2020; Published: 6 September 2020

\begin{abstract}
Infections by the Burkholderia cepacia complex (Bcc) remain seriously life threatening to cystic fibrosis $(\mathrm{CF})$ patients, and no effective eradication is available. A vaccine to protect patients against Bcc infections is a highly attractive therapeutic option, but none is available. A strategy combining the bioinformatics identification of putative surface-exposed proteins with an experimental approach encompassing the "shaving" of surface-exposed proteins with trypsin followed by peptide identification by liquid chromatography and mass spectrometry is here reported. The methodology allowed the bioinformatics identification of 263 potentially surface-exposed proteins, 16 of them also experimentally identified by the "shaving" approach. Of the proteins identified, 143 have a high probability of containing B-cell epitopes that are surface-exposed. The immunogenicity of three of these proteins was demonstrated using serum samples from Bcc-infected CF patients and Western blotting, validating the usefulness of this methodology in identifying potentially immunogenic surface-exposed proteins that might be used for the development of Bcc-protective vaccines.
\end{abstract}

Keywords: Burkholderia cepacia complex; surface-exposed moieties; liquid chromatography-tandem mass spectrometry (LC-MS/MS); immunoreactive proteins; cystic fibrosis; serum samples; immunoreactivity

\section{Introduction}

The Burkholderia cepacia complex (Bcc) presently comprises at least 23 closely related bacterial species [1-3] that emerged in the 1980s as important pathogens for patients suffering from cystic fibrosis (CF). Bcc bacteria can be found in a wide range of environments including water, soil and the rhizosphere of plants, being able to survive in hospital settings and pharmaceutical aqueous solutions [4]. Despite their presence in the environment, Bcc bacteria are opportunistic pathogens capable of causing life-threatening infections in the respiratory tract of immunocompromised patients, patients with chronic granulomatous disease (CGD) and especially patients suffering from CF, the most common lethal inherited genetic disease among Caucasians [5]. The majority of Bcc-infected CF patients experience an increased decline in pulmonary function, which is associated with chronic infection and exacerbation episodes [5]. However, some patients can also develop a rapid and fatal necrotizing pneumonia known as the cepacia syndrome $[5,6]$. These factors, coupled with the organism's armory of virulence factors and the intrinsic resistance of Bcc bacteria to several clinically available antimicrobials, render chronic infections virtually untreatable [5,7-9], making infections by Bcc a major concern since 
the clinical outcome is highly variable and unpredictable [10]. Considering all the above, a strategy to eradicate Bcc bacteria from $\mathrm{CF}$ patients is imperative. Since there is no eradication therapy presently available [11], new strategies to deal with Bcc infections are of major interest. Currently, no such strategies exist, but a wide variety of approaches and antigens are under study for the development of a possible vaccine against Bcc [12-15].

Bacteria use the proteins expressed on their surface to interact with their environment, being also exposed to the immune system of the host. Therefore, surface-exposed proteins are appealing antigens for the development of new therapeutic strategies for the eradication of bacterial infections [16]. However, a wide range of characteristics including low abundance, hydrophobic natures and low solubility make these proteins difficult to study, especially using first-generation gel-dependent proteomics approaches [17-19]. In order to uncover novel surface-exposed antigens to be studied for the development of new therapeutic strategies for the eradication of Bcc infections, a bioinformatics analysis of the surface-exposed proteins of B. cenocepacia J2315 and their immune profile was performed in this work. The proteins identified were experimentally validated using a surface "shaving" approach comprising the digestion of live intact cells with proteases and the recovery of the cells' surface-exposed moieties, followed by their analysis by liquid chromatography-tandem mass spectrometry (LC-MS/MS) (Figure 1). In this way, using a sensitive and gel-free approach, the limitations associated with membrane protein analysis can be overcome. This approach also grants the acquisition of new information, as it allows the identification of the domains of the identified proteins that are more accessible to proteases and therefore to the host immune system and antibodies [17]. The surface "shaving" approach has been applied mainly to Gram-positive bacteria, owing to their characteristic thicker cell walls that confer a greater resistance to cell lysis. Nonetheless, it has also been applied to Gram-negative bacteria, unicellular fungi and also larvae of parasitic helminth worms [17,20-22]. Different levels of success were reported in each case, depending on factors such as protein structure and microorganism surface topology.

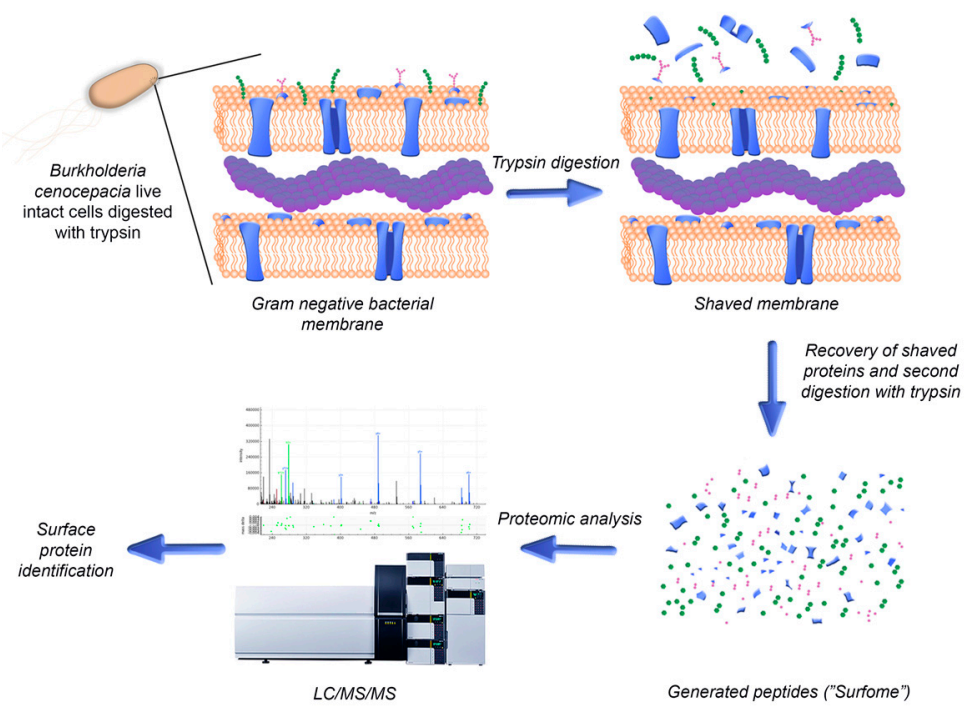

Figure 1. Schematic representation of the steps involved in the identification of surface-exposed proteins using the surface-shaving approach for live B. cenocepacia cells.

Despite the increase in popularity of this technique, it had never been applied to bacteria of the $\mathrm{Bcc}$, and therefore, this pioneering work was envisioned. With this purpose, and to discover surface proteins exposed to the host during the infection process, the protocol was optimized for B. cenocepacia J2315 using growth conditions that mimic the environment in the lungs of CF patients. The CF lung has steep oxygen gradients, usually with low oxygen concentrations within the typically thick mucus 
layer [23]. Bcc bacteria can also survive intracellularly in host cells, where they are exposed to low $\mathrm{pH}$, severe nutrient limitation and oxidative stress [24].

The bioinformatics approach used in this work allowed us to identify 263 surface-exposed proteins, 143 of them having a high probability of containing predicted immunogenic surface-exposed regions. Using the experimental surface-shaving optimized protocol, we were able to confirm that 16 of the identified proteins were in fact surface-exposed, and their exposed moieties were identified. Three selected proteins were cloned, overexpressed, purified and confirmed as immunoreactive with the sera of $\mathrm{CF}$ patients with a record of infections with Bcc.

\section{Materials and Methods}

\subsection{Bacterial Strains and Culture Conditions}

The bacterial strains and plasmids used are shown in Table 1. PIA (Pseudomonas Isolation Agar, Becton Dickinson, Heidelberg, Germany) and Lennox broth (LB, containing, in g/L, tryptone, 10; yeast extract, 5; $\mathrm{NaCl}, 5$; and agar, 20) were used, respectively, to maintain B. cenocepacia J2315 and Escherichia coli strains. When appropriate, LB was supplemented with $150 \mu \mathrm{g} / \mathrm{mL}$ ampicillin or $50 \mu \mathrm{g} / \mathrm{mL}$ kanamycin. Unless otherwise stated, bacteria were cultivated in shaking flasks ( $250 \mathrm{rev} / \mathrm{min})$ containing LB liquid at $37^{\circ} \mathrm{C}$, supplemented with adequate antibiotics.

Table 1. Bacterial strains and plasmids used in this work. $A p^{R}$, resistant to ampicillin; $\operatorname{Kan}^{\mathrm{R}}$, resistant to kanamycin.

\begin{tabular}{|c|c|c|}
\hline Strain or Plasmid & Genotype or Description & Source or Reference \\
\hline B. cenocepacia J2315 & $\begin{array}{l}\text { Cystic Fibrosis isolate; ET12 lineage reference } \\
\text { strain, genome sequence available. }\end{array}$ & [25] \\
\hline E. coli $\mathrm{DH} 5 \alpha$ & $\begin{array}{c}\mathrm{F}^{-} \text {Ф80lacZ } \Delta \mathrm{M} 15 \Delta(\text { lacZYA-argF }) \mathrm{U} 169 \text { recA1 } \\
\text { endA1 hsdR17 }\left(\mathrm{r}_{\mathrm{k}}{ }^{-}, \mathrm{m}_{\mathrm{k}}{ }^{+}\right) \text {phoA sup } 44 \text { thi-1 } \\
\text { gyrA96 relA1 } \lambda^{-}\end{array}$ & Invitrogen (Carlsbad, CA, USA) \\
\hline E. coli BL21 (DE3) & $\mathrm{F}^{-}$ompT hsdSB (rB-mB-) dcm gal $\lambda(\mathrm{DE} 3)$ & Stratagene (San Diego, CA, USA) \\
\hline \multicolumn{3}{|l|}{ Plasmids } \\
\hline pET23a+ & $\begin{array}{l}\text { Cloning/expression vector, T7 promoter, } \\
\text { C-terminal 6x His-Tag, } \mathrm{Ap}^{\mathrm{r}}\end{array}$ & Novagen (Madison, WI, USA) \\
\hline pET29a+ & $\begin{array}{c}\text { Cloning/expression vector, T7 promoter, } \\
\text { thrombin recognition site, C-terminal } 6^{\prime} \\
\text { His-Tag, Kan }{ }^{\mathrm{r}}\end{array}$ & Novagen \\
\hline pSAS38 & $\begin{array}{l}\text { pET23a+ containing the pET29a+ thrombin } \\
\text { recognition site, cloned downstream of the T7 } \\
\text { promoter and upstream of the C-terminal } 6 \times \\
\text { His-Tag, Ap }\end{array}$ & This study \\
\hline pMM1 & $\begin{array}{l}\text { pSAS38 containing the BCAL2022 gene, } \\
\text { cloned downstream of the T7 promoter, } \mathrm{Ap}^{\mathrm{r}}\end{array}$ & This study \\
\hline pSAS36 & $\begin{array}{l}\text { pET23a+ containing the BCAL2645 gene, } \\
\text { cloned downstream of the T7 promoter and } \\
\text { upstream of the C-terminal } 6 \times \text { His-Tag, } \mathrm{Ap}^{\mathrm{r}}\end{array}$ & This study \\
\hline pSAS6 & $\begin{array}{l}\text { pET23a+ containing the BCAL2958 gene, } \\
\text { cloned downstream of the T7 promoter and } \\
\text { upstream of the C-terminal } 6 \times \text { His-Tag, } \mathrm{Ap}^{\mathrm{r}}\end{array}$ & {$[26]$} \\
\hline
\end{tabular}

\subsection{Digestion of Live B. cenocepacia Cells' Surface with Trypsin}

The generation and recovery of peptides by "shaving" B. cenocepacia J2315 cells with trypsin was performed based on the work of Rodríguez-Ortega (2018) with slight adaptations [27]. After bacterial growth until mid-exponential phase under the conditions indicated in Materials and Methods, the cultures' optical densities at $600 \mathrm{~nm}\left(\mathrm{OD}_{600}\right)$ were normalized to 0.5 . Aliquots of $100 \mu \mathrm{L}$ of the bacterial suspensions were spread onto the surfaces of Artificial Sputum Medium (ASM) agar plates. The composition of 
the ASM was formulated to mimic CF patients' sputum. The ASM solid medium contained, in $\mathrm{g} / \mathrm{L}$, porcine stomach mucin (Sigma-Aldrich, St. Louis, MO, USA) 5.0; low molecular-weight salmon sperm DNA (Sigma-Aldrich, St. Louis, MO, USA), 4.0; NaCl (Sigma-Aldrich, St. Louis, MO, USA), 5.0; KCl (Sigma-Aldrich, St. Louis, MO, USA), 2.2; casamino acids (Difco Laboratories, Detroit, MI, USA), 5.0; Tris Base (Sigma-Aldrich, St. Louis, MO, USA), 1.81; and agar, 20 (pH 7.0), with $5.0 \mathrm{~mL} / \mathrm{L}$ of egg yolk emulsion as a source of lecithin (Sigma-Aldrich, St. Louis, MO, USA) and $5.9 \mathrm{mg} / \mathrm{L}$ of the iron-chelating agent diethylene triamine pentaacetic acid (DTPA) (Sigma-Aldrich, St. Louis, MO, USA) [28]. After incubation for $22 \mathrm{~h}$ at $37^{\circ} \mathrm{C}$ under aerobic conditions, cells were scraped from the ASM agar plates' surface with phosphate-buffered saline solution (PBS; $8.18 \mathrm{~g} / \mathrm{L} \mathrm{NaCl}, 0.2 \mathrm{~g} / \mathrm{L} \mathrm{KCL}$, $2.68 \mathrm{~g} / \mathrm{L} \mathrm{Na}_{2} \mathrm{HPO}_{4}$ and $0.245 \mathrm{~g} / \mathrm{L} \mathrm{NaH} \mathrm{PO}_{4}$., $\mathrm{pH} 7.4$ ) and harvested by centrifugation at $3500 \times \mathrm{g}$ for $5 \mathrm{~min}$ at $20^{\circ} \mathrm{C}$. The pelleted bacteria were washed thrice with PBS and finally resuspended in $1 \mathrm{~mL}$ of PBS. Tryptic digestion was carried out with $2.5 \mu \mathrm{g} / \mathrm{mL}$ porcine trypsin (sequencing grade; Promega, Madison, WI, USA) for $10 \mathrm{~min}$ at $37^{\circ} \mathrm{C}$ with gentle agitation. The digestion mixtures were centrifuged at $3500 \times \mathrm{g}$ for $5 \mathrm{~min}$ at $4{ }^{\circ} \mathrm{C}$, and the supernatants (the "surfome" containing the peptides) were filtered using $0.22 \mu \mathrm{m}$-pore-sized syringe filters (Whatman ${ }^{\mathrm{TM}}$, Buckinghamshire, UK). The surfome was re-digested with $1 \mu \mathrm{g} / \mathrm{mL}$ trypsin overnight at $37^{\circ} \mathrm{C}$ with gentle agitation. The solution containing the peptides was stored at $-80^{\circ} \mathrm{C}$ until further analysis. Aliquots $(15 \mu \mathrm{L})$ of the tryptic digestion mixtures were separated by $15 \%$ SDS-polyacrylamide gel electrophoresis (PAGE). The gel was silver stained according to the protocol of Chevallet et al. (2006) [29].

\subsection{Bacterial Cell Viability Assay}

For the analysis of bacterial viability, $10 \mu \mathrm{L}$ of the bacterial suspensions were taken pre- and post-trypsin digestion. The samples were serially diluted $\left(10^{-1}\right.$ to $\left.10^{-8}\right)$ with $0.9 \%(\mathrm{~W} / \mathrm{V}) \mathrm{NaCl}$, and the different dilutions were spotted on LB agar plates. The plates were incubated overnight at $37^{\circ} \mathrm{C}$, and the total colony forming units (CFUs) were determined for each sample.

\subsection{Cleaning of Peptides with Solid-Phase Extraction Cartridges}

After bacterial cell removal, the peptides that resulted from the digestion of the live bacterial cells with trypsin were cleaned and concentrated using Oasis HLB extraction cartridges (Waters, NY, USA), following the manufacturer's instructions and as modified by Rodríguez-Ortega [27]. Briefly, $150 \mu \mathrm{L}$ samples were loaded into extraction cartridges previously conditioned with $80 \%$ acetonitrile (ACN), followed by $0.1 \%$ formic acid solution. Peptides were eluted from the extraction cartridges using increasing concentrations of $\mathrm{ACN}(10,20$ and $50 \%$ ) in $0.1 \%$ formic acid. Peptide fractions were dried using a vacuum concentrator (Eppendorf, Hamburg, Germany), resuspended in $100 \mu \mathrm{L}$ of a solution containing $2 \% \mathrm{ACN}$ and $0.1 \%$ formic acid and kept at $-20{ }^{\circ} \mathrm{C}$ until further processing.

\subsection{MALDI-TOF MS Analysis}

The efficiency of the tryptic digestion of the live bacterial cells was checked at the qualitative level by looking at the mass spectrum from MALDI-TOF MS. Aliquots of $1 \mu \mathrm{L}$ of the cleaned peptides were mixed with $1 \mu \mathrm{L}$ of matrix solution ( $\alpha$-cyanohydroxycinnamic acid at a concentration of $5 \mathrm{mg} / \mathrm{mL}$ in $70 \% \mathrm{ACN} / 0.1 \%$ trifluoroacetic acid) and spotted onto a MALDI plate using the dry-droplet method. A 4800 Proteomics Analyzer MALDI-TOF/TOF Mass Spectrometer (Applied Biosystems, Waltham, MA, USA) was used to acquire the mass spectra, in the $\mathrm{m} / \mathrm{z}$ range of 800 to 4000 , with an accelerating voltage of $20 \mathrm{kV}$ in reflectron mode. The spectra were internally calibrated using peptides from trypsin autolysis $\left(\left[\mathrm{M}+\mathrm{H}^{+}\right]=842.509,\left[\mathrm{M}+\mathrm{H}^{+}\right]=2211.104\right)$ with an $m / z$ precision of $\pm 20 \mathrm{ppm}$.

\subsection{LC-MS/MS Analysis}

A Dionex Ultimate 3000 nano UPLC (Thermo Scientific, San Jose, CA, USA), equipped with a reverse phase C18 $75 \mu \mathrm{m} \times 50 \mathrm{~mm}$ Acclaim PepMap Column (Thermo Scientific) was used for peptide separation. The system was operated for a total run time of $85 \mathrm{~min}$ at a flow rate of $300 \mathrm{~nL} / \mathrm{min}$ and 
$40{ }^{\circ} \mathrm{C}$. The peptide mix was previously concentrated and cleaned up using a $300 \mu \mathrm{m} \times 5 \mathrm{~mm}$ Acclaim PepMap cartridge (Thermo Scientific) in $2 \% \mathrm{ACN} / 0.05 \%$ formic acid for $5 \mathrm{~min}$, at a $5 \mu \mathrm{L} / \mathrm{min}$ flow rate. The mobile phase used for the chromatographic separation was composed of Solution A $(0.1 \%$ formic acid) and Solution B ( $80 \%$ ACN, $0.1 \%$ formic acid). The elution conditions used were as follows: $4-35 \%$ Solution B for $60 \mathrm{~min}, 35-55 \%$ Solution B for $3 \mathrm{~min}$, and 55-90\% Solution B for $3 \mathrm{~min}$, followed by 8 min of washing with $90 \%$ Solution B and re-equilibration for 12 min with $4 \%$ Solution B. Peptide positive ions were eluted and ionized by a nano-electrospray ionization source and further analyzed in positive mode on a trihybrid Thermo Orbitrap Fusion (Thermo Scientific) mass spectrometer, operating in the Top30 Data-Dependent Acquisition mode. A $3 \mathrm{~s}$ maximum cycle time was used. Peptide-precursor single MS scans were acquired in a 400-1500 $\mathrm{m} / \mathrm{z}$ range at 120,000 resolution (at 200 $\mathrm{m} / \mathrm{z}$ ), with a $4 \times 10^{5}$ ion count target threshold. For MS/MS, precursor ions were previously isolated in the quadrupole at 1.2 Da and then collision induced fragmentation (CID)-fragmented in the ion trap with 35\% normalized collision energy. The monoisotopic precursor selection was turned on. The ion trap parameters were (i) the automatic gain control was $2 \times 10^{3}$, (ii) the maximum injection time was $300 \mathrm{~ms}$, and (iii) only those precursors with charge state $2-5$ were sampled for MS/MS. In order to avoid redundant fragmentations, the dynamic exclusion time was set to $15 \mathrm{~s}$, with a $10 \mathrm{ppm}$ tolerance around the selected precursor and its isotopes.

\subsection{Protein Identification by Database Searching}

The mass spectrometry raw data were processed using the Proteome Discoverer software (version 2.1.0.81, Thermo Scientific). Charge state deconvolution and deisotoping were not performed. The SEQUEST engine was used to search the MS/MS spectra against the B. cenocepacia J2315 genome database downloaded from UniProt (www.uniprot.org), using the following search parameters: one missed cleavage allowed for trypsin digestion, methionine oxidation set as a variable modification, a value of $10 \mathrm{ppm}$ set for the mass tolerance for the precursor ions, and a $0.1 \mathrm{Da}$ tolerance for the ion products. Peptide identifications were accepted only when they exceeded the filter parameter Xcorr score versus charge state with SequestNode Probability Score $(+1=1.5,+2=2.0,+3=2.25$, $+4=2.5$ ). Peptide spectral matches (PSM) were validated at a $1 \%$ FDR, using a percolator based on q-values. B. cenocepacia J2315 surface-associated proteins identified using the "surface shaving" were characterized with regard to subcellular localization and associated biological and molecular functions using The Burkholderia Genome Database, PSORTb 3.0.2 and Pfam 33.1 bioinformatics tools [30-32]. The mass spectrometry raw data have been deposited at PeptideAtlas (www.peptideatlas.org), with the dataset identifier PASS01615.

\subsection{Molecular Biology Techniques}

Total DNA was extracted from B. cenocepacia strain J2315 cells harvested from liquid cultures at the exponential growth phase using the High Pure PCR Template Preparation Kit (Roche, Basel, Switzerland). Techniques including plasmid isolation and purification (NZYTech, Lisbon, Portugal), DNA amplification, DNA restriction and T4 DNA ligation (Thermo Fisher Scientific), agarose gel electrophoresis, SDS-PAGE, and E. coli transformation were performed using standard procedures [33]. The primers used for the amplification of the gene BCAL2645 were UP-BCAL2645 (5'-TGACATATGAACATGAAAATCGC-3') and LW-BCAL2645 (5'-AACTCGAGCTGATGCTGTTGC-3'), containing the NdeI and XhoI restriction sites (underlined), respectively, at their $5^{\prime}$ ends. Nested polymerase chain reaction (PCR) was used to amplify the gene $B C A L 2022$. This involved two sequential amplification reactions. In the first reaction, the primer pair used was Nested_UP-BCAL2022 (5'-TTTCAACCACGGAGGATTTC-3') and Nested_LW-BCAL2022 (5'-GACAGCAACATCAGCGAGAG-3'). The second PCR reaction used the product of the first PCR reaction as the template and the primers UP-BCAL2022 (5'-TTCATATGTCGCTTTTCGACTC-3') and LW-BCAL2022 (5'-AAGGTACCCTGCGCGGGCG-3'), containing, respectively, the NdeI and KpnI 
restriction sites (underlined) at their $5^{\prime}$ ends. All the primers were designed based on the B. cenocepacia J2315 genome sequence (available at [34]) and acquired from STAB VIDA (Portugal) via a paid service.

\subsection{Cloning and Overexpression of B. cenocepacia J2315 bcal2022, bcal2645 and bcal2958 Proteins}

The gene BCAL2645 was cloned using the plasmid pET23a+ and the $659 \mathrm{bp}$ PCR product obtained using the primers UP-BCAL2645 and LW-BCAL2645, digested with the restriction enzymes NdeI and XhoI. The BCAL2645 fragment was ligated into the NdeI/XhoI-digested pET23a+, yielding pSAS36. The gene BCAL2022 was cloned in the plasmid pSAS38. The $681 \mathrm{bp}$ PCR product obtained using primers UP-BCAL2022 and LW-BCAL2022 was digested with the restriction enzymes NdeI and KpnI, and the BCAL2022 fragment was ligated into the NdeI/KpnI-digested pSAS38, yielding the construct pMM1. The plasmid pSAS38 was previously created by cloning the thrombin recognition site of pET29a $a^{+}$in the pET23a $a^{+}$The nucleotide sequences of the cloned fragments were confirmed by sequencing (Eurofins Genomics, Ebersberg, Germany).

Plasmids pSAS36 and pMM1 allow, respectively, the controlled expression of C-terminus $6 \times$ His-tag derivatives of the proteins BCAL2645 and BCAL2022, upon induction of the T7 promoter by isopropyl $\beta$-D-thiogalactoside (IPTG). E. coli BL21 (DE3) transformed with each plasmid were cultivated in $100 \mathrm{~mL}$ of LB liquid medium supplemented with $150 \mu \mathrm{g} / \mathrm{mL}$ ampicillin at $37^{\circ} \mathrm{C}$ (pSAS36) or $30^{\circ} \mathrm{C}$ (pMM1) and with orbital shaking $\left(250 \mathrm{rpm}\right.$ ). When the cultures reached an $\mathrm{OD}_{640}$ of 0.6 , IPTG was added to a $0.4 \mathrm{mM}$ final concentration and the cultures were incubated for an additional $2 \mathrm{~h}$ under the same temperature and orbital-agitation conditions. Bacteria were harvested by centrifugation for $5 \mathrm{~min}$ at $7000 \times \mathrm{g}$ and $4{ }^{\circ} \mathrm{C}$. The resulting pellets were resuspended in $10 \mathrm{~mL}$ of sonication buffer ( $20 \mathrm{mM}$ sodium phosphate, $500 \mathrm{mM} \mathrm{NaCl}, 20 \mathrm{mM}$ imidazole, $\mathrm{pH} 7.4$ ) and stored at $-80{ }^{\circ} \mathrm{C}$ until further processing. Recombinant $6 \times$ His-tagged BCAL2645 and BCAL2022 production was assessed by SDS-PAGE analysis, followed by immunoblotting experiments using a monoclonal anti-polyhistidine peroxidase conjugate clone HIS-1 antibody (diluted 1:2000, Sigma, St. Louis, MO, USA), as previously described [26]. BCAL2958 overexpression was performed as previously described [26].

\subsection{Purification of B. cenocepacia J2315 His-Tagged Proteins BCAL2022, BCAL2645 and BCAL2958}

Bacterial suspensions of recombinant $E$. coli used to overexpress proteins were lysed by ultrasonic vibration with a Branson sonifier 250 (Branson Ultrasonics, Brookfield, CT, USA), using 6 cycles of sonication of $30 \mathrm{~s}$ each with a $40 \%$ duty cycle, adding $2 \%(\mathrm{v} / \mathrm{v})$ Triton X-100 before the last two sonication cycles. Centrifugation at $12,000 \times \mathrm{g}$ for $30 \mathrm{~min}$ at $4{ }^{\circ} \mathrm{C}$ was then performed to remove non-soluble cell debris. The cleared supernatants were collected and kept at $4{ }^{\circ} \mathrm{C}$. The BCAL2645 and BCAL2022 $6 \times$ His-tagged proteins were then purified by affinity chromatography using HisTrap FF columns (GE Healthcare, Chicago, IL, USA). The columns were initially equilibrated by flowing $10 \mathrm{~mL}$ of Buffer A (20 mM sodium phosphate, $750 \mathrm{mM} \mathrm{NaCl}, 20 \mathrm{mM}$ imidazole, $10 \%$ glycerol, $\mathrm{pH}$ 7.4) for BCAL2645 or Buffer B ( $20 \mathrm{mM}$ sodium phosphate, $500 \mathrm{mM} \mathrm{NaCl}, 20 \mathrm{mM}$ imidazole, $\mathrm{pH} 7.4$ ) for BCAL2022. The proteins were then eluted with $5 \mathrm{~mL}$ of Buffer A or B, respectively, containing imidazole concentrations of 60,100, 150, 200, 250,300, 400 and $500 \mathrm{mM}$. Aliquots of $1 \mathrm{~mL}$ were collected for each protein, followed by their analysis by SDS-PAGE. Immunoblotting experiments were carried out as previously described using a commercial monoclonal anti-polyhistidine peroxidase conjugate clone HIS-1 antibody (Sigma; St. Louis, MO, USA) [26]. BCAL2958 purification was performed as previously described [26].

\subsection{CF Patients' Blood Sera's Immunoreactivity against the Proteins BCAL2022, BCAL2645 and BCAL2958}

The His-tagged purified proteins BCAL2022, BCAL2645 and BCAL2958, as well as the negative control bovine serum albumin (BSA) (Nzytech), were loaded into 15\% SDS-PAGE gels and subjected to electrophoresis for $1 \mathrm{~h}$ at $160 \mathrm{~V}$ using standard procedures [33]. The gels were then equilibrated for $15 \mathrm{~min}$ in transfer buffer (48 mM Tris, $39 \mathrm{mM}$ glycine, $20 \%$ (V/V) methanol, $0.04 \%$ (W/V) SDS, $\mathrm{pH}$ 9.2). After this time, the proteins were electrotransferred to nitrocellulose (NC) membranes (PALL 
corporation, Port Washington, NY, USA) using a Trans-Blot ${ }^{\circledR}$ SD (BIORAD, Hercules, CA, USA) device apparatus at $15 \mathrm{~V}$ and $120 \mathrm{~mA}$ for $1 \mathrm{~h}$. After protein electrotransfer, the membranes were blocked overnight at $4{ }^{\circ} \mathrm{C}$ with $5 \%(\mathrm{w} / \mathrm{v})$ skim milk (Difco Laboratories, Detroit, MI, USA) in PBS. The membranes were then probed for $3 \mathrm{~h}$ at room temperature with individual serum samples from CF patients (1:1000 dilution) or with a commercial pool of human sera from healthy donors (1:1000 dilution, S7023, Sigma, St. Louis, MO, USA). Serum samples were obtained from blood samples collected from two CF patients with a clinical record of Bcc infection who attended the Santa Maria hospital in Lisbon, Portugal, as previously described [19]. The membranes were washed with PBS-T (PBS containing $0.05 \%(\mathrm{v} / \mathrm{v})$ Tween 20) and then incubated for $1 \mathrm{~h}$ at room temperature with a secondary antibody horseradish peroxidase (HRP)-conjugated rabbit anti-human IgG (1:5000 dilution, Santa Cruz Biotechnology, Dallas, TX, USA). After the removal of the secondary antibody and a wash with PBS-T, the membranes were treated with the peroxidase substrate ECL (Sigma, St. Louis, MO, USA) and signals were detected using the FUSION Solo apparatus (Vilber Lourmat, Collégien, France).

\subsection{Enzyme-Linked Immunosorbent Assay (ELISA)}

Quantification of the IgG levels present in the serum samples from CF patients with a clinical history of Bcc infection against purified 6x His-tagged BCAL2645 was performed by enzyme-linked immunosorbent assay (ELISA) as previously described [26]. Briefly, the BCAL2645 protein was diluted to $2 \mu \mathrm{g} / \mathrm{mL}$ in $100 \mathrm{mM}$ sodium carbonate buffer ( $\mathrm{pH}$ 9.6), and $100 \mu \mathrm{L}$ was applied per well to 96-well ELISA plates (Greiner Microlon 600, Greiner Bio-One, Kremsmünster, Austria). After overnight incubation at $4{ }^{\circ} \mathrm{C}$, the plates were blocked with $250 \mu \mathrm{L}$ of $3 \% \mathrm{BSA} / \mathrm{PBS}$ overnight at $4{ }^{\circ} \mathrm{C}$. The serum samples to be tested were serially diluted $(1: 100$ to $1: 10,000)$ in 3\% BSA/PBS-T (PBS supplemented with $0.05 \%$ Tween 20 ). After the addition of the diluted serum samples to the plates, they were incubated $2 \mathrm{~h}$ at $25^{\circ} \mathrm{C}$. Then, the plates were washed with PBS-T, and $100 \mu \mathrm{L}$ of HRP-conjugated rabbit anti-human IgG (Santa Cruz Biotechnology) antibody at 1:3000 dilution in 3\% BSA/PBS-T was added to the plates. After incubation at $25^{\circ} \mathrm{C}$ for $1 \mathrm{~h}$, the plates were washed with PBS-T. Then, $100 \mu \mathrm{L}$ of the peroxidase substrate 3,3',5,5' -tetramethylbenzidine (TMB, Sigma-Aldrich, St. Louis, MO, USA) were added. After incubation for $20 \mathrm{~min}$ at $25^{\circ} \mathrm{C}$, the reaction was stopped by the addition of $100 \mu \mathrm{L}$ of $0.5 \mathrm{M} \mathrm{H}_{2} \mathrm{SO}_{4}$. The plates were read at $450 \mathrm{~nm}$ in the SPECTROstar Nano Microplate Reader (BMG LABTECH, Ortenberg, Germany). A pool of sera from healthy humans (Sigma-Aldrich, St. Louis, MO, USA) was used as control. Internal positive and negative controls were included in each plate. All serum samples were analyzed in triplicate with at least two independent experiments.

Serum antibody concentrations were defined as endpoint titers and were calculated as the reciprocal of the highest serum dilution producing an $\mathrm{OD}_{450}$ above the cut-off value. The cut-off value was determined as the mean $\mathrm{OD}_{450}$ of the negative control plus 3 standard deviations. A titer above the cut-off value was considered a positive result for the ELISA.

\subsection{Bioinformatics Analysis}

The proteins identified by bioinformatics tools as extracellular or present in the outer membrane were selected using the Burkholderia Genome Database [30]. With this purpose, a search using the subcellular localization annotation was performed. The amino acid sequences of the proteins selected for being extracellular or present in the outer membrane were retrieved from the genome sequence of $B$. cenocepacia J2315, available at the above-referenced database. The sequences were further analyzed for B-cell epitopes using BepiPred-2.0, in the immune epitope database (IEDB), using a 0.5 threshold [35]. This 0.5 threshold was used because it is the point at which sensitivity and specificity are both maximized in BepiPred 2.0. Peptides shorter than five or larger than 25 amino acids were not considered, as B-cell epitopes are usually within this size range [35]. 


\section{Results}

3.1. Identification and Analysis of Surface-Exposed Proteins of B. cenocepacia J2315 with Immunogenic Epitopes Using Bioinformatics Tools

The Burkholderia Genome Database [30] was used to search for extracellular or outer membrane-encoding genes. A total of 161 genes putatively coding for outer membrane proteins and 102 genes coding for putative extracellular proteins were identified (Tables S1 and S2). The amino acid sequences of these proteins were then retrieved from the genome sequence of B. cenocepacia J2315, available at the above-referenced database. B-cells are a fundamental component of the adaptive immune system, having the ability to recognize and provide long-term protection against infectious pathogens [36]. These cells produce antibodies that recognize their molecular target (called antigen) by binding to a part of it, the epitope, in a highly selective manner. This recognition process can be used for the development of vaccines to provide long-term protection against infectious pathogens. Therefore, the putative 263 surface-exposed proteins identified were inspected for linear B-cell epitopes using the BepiPred-2.0 tool. Peptides shorter than five or larger than 25 amino acids were not considered, as B-cell epitopes are usually within this size range [35]. A total of 143 proteins were found as having a high probability of being immunogenic, presenting an average of B-cell epitopes higher than 0.5. The predicted B-cell epitopes for each protein identified are shown in Tables S1 and S2.

\subsection{Characterization of Surface-Exposed Proteins Using Trypsin Digestion of Live B. cenocepacia J2315 Cells}

In order to validate the bioinformatically identified proteins as surface-exposed proteins, a surface-shaving protocol using trypsin was optimized for live cells of B. cenocepacia J2315, grown in conditions that mimic the CF lung, combined with the subsequent LC-MS/MS analysis of the generated peptides.

\subsubsection{Optimization of "Shaving" Protocol}

In order to mimic the CF lung environment, B. cenocepacia J2315 was inoculated in ASM agar plates. ASM is composed of components similar to the constituents of CF sputum, including free DNA, mucin, a lecithin source, an iron-chelating agent, salts and amino acids at concentrations similar to those in the average CF patient's sputum [28]. The protocol for the surface "shaving" with trypsin of live cells is a compromise between the efficiency of protease-generated peptides and the avoidance of contamination with cytoplasmic proteins [37]. Therefore, to obtain minimal cell lysis of B. cenocepacia J2315, the protocol for the surface shaving with trypsin of live cells was optimized. Several buffers previously used for "shaving" protocols for other bacteria were tested, such as PBS containing 30\% sucrose (pH 7.4), PBS containing 10\% sucrose (pH 7.4), $10 \mathrm{mM} \mathrm{HEPES} \mathrm{(pH} \mathrm{7.4)} \mathrm{and}$ PBS ( $\mathrm{pH}$ 7.4) [20]. Therefore, aliquots before and after the digestion of B. cenocepacia cells with trypsin $\left(30 \mathrm{~min}\right.$ at $37^{\circ} \mathrm{C}$ ) were serially diluted and spot inoculated on LB agar to determine total CFUs. The PBS buffers supplemented with sucrose and the HEPES buffer resulted in the lysis of more than $54 \%$ of the B. cenocepacia cells. Instead, a 22\% lysis was determined for the cells digested with PBS. Therefore, PBS was selected, different concentrations of trypsin $(2.5$ or $5 \mu \mathrm{g} / \mathrm{mL})$ and incubation times (10 or $30 \mathrm{~min})$ at $37^{\circ} \mathrm{C}$ were also tested, and the aliquots containing the tryptic digestion mixtures were separated by SDS-PAGE and visualized after silver staining (Figure 2). After the "shaving" protocol optimization, the best condition that enabled lower B. cenocepacia J2315 cell lysis and higher digestion of the exposed domains of surface proteins with trypsin was the incubation of cells with $2.5 \mu \mathrm{g} / \mathrm{mL}$ in PBS for $10 \mathrm{~min}$. 


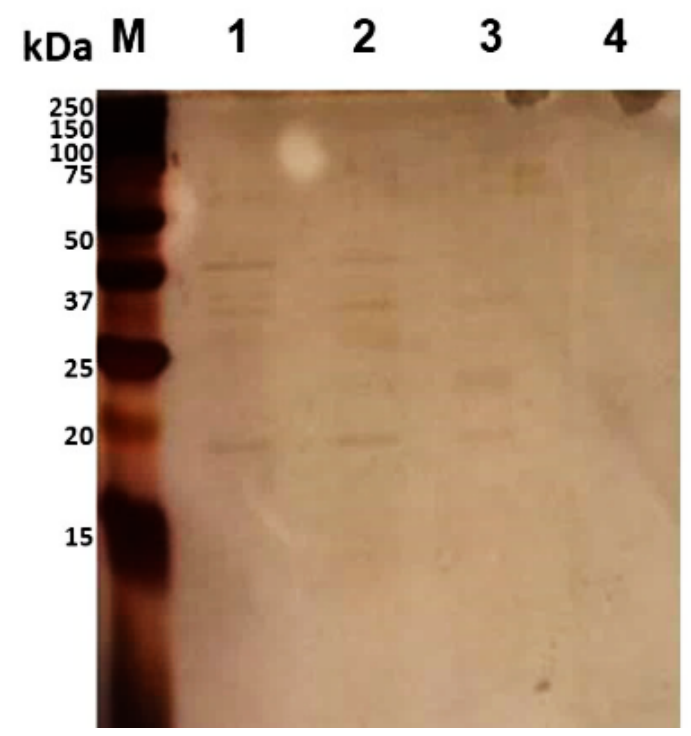

Figure 2. Separation of trypsin-digested mixtures of B. cenocepacia $\mathrm{J} 2315$ by $15 \%$ SDS-PAGE, followed by silver staining. Lanes: $\mathbf{M}$-Precision Plus Protein ${ }^{\mathrm{TM}}$ DualXtra Standard (BIORAD); 1 -bacteria shaved with trypsin $(5 \mu \mathrm{g} / \mathrm{mL})$ in PBS, pH 7.4, for $30 \mathrm{~min}$ at $37^{\circ} \mathrm{C} ; 2$-bacteria shaved with trypsin $(5 \mu \mathrm{g} / \mathrm{mL})$ in PBS for $10 \mathrm{~min}$ at $37^{\circ} \mathrm{C}$; 3-bacteria shaved with trypsin $(2.5 \mu \mathrm{g} / \mathrm{mL})$ in PBS for $10 \mathrm{~min}$ at $37^{\circ} \mathrm{C} ; 4$ - control sample-bacteria without trypsin digestion in PBS.

After digestion with trypsin, bacterial cells were removed by centrifugation and the supernatants were filtered to remove any remaining bacterial cells. To determine if one trypsin digestion was sufficient to generate small peptides for LC-MS/MS analysis, the surfome samples before and after re-digestion with $1 \mu \mathrm{g} / \mathrm{mL}$ trypsin overnight at $37^{\circ} \mathrm{C}$ were analyzed by MALDI-TOF MS analysis (Figure 3). As expected, the second digestion led to a significant increase in the number of peptides. Therefore, a second digestion with trypsin was performed before LC-MS/MS analysis.

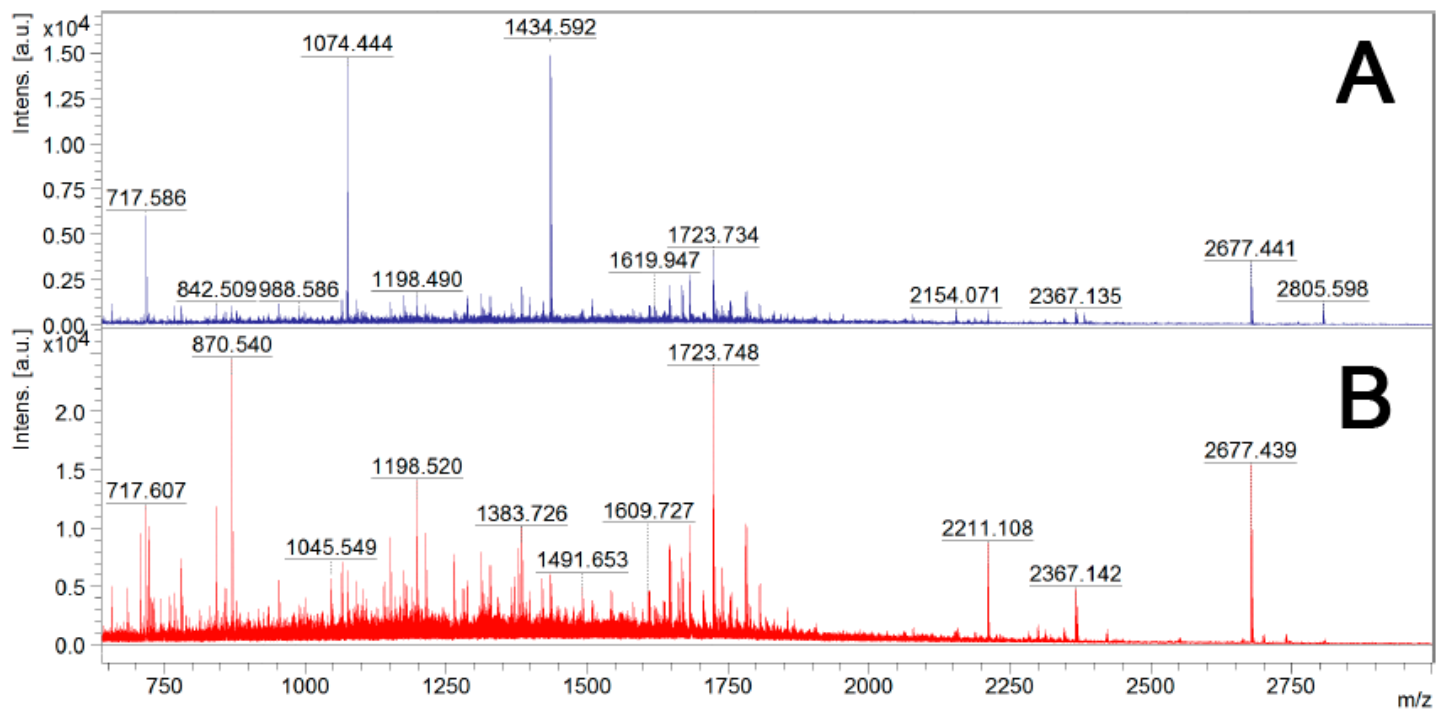

Figure 3. Mass spectra from MALDI-TOF MS of trypsin-digested samples of live B. cenocepacia J2315 cells. Sample A-Single trypsin digestion: $2.5 \mu \mathrm{g} / \mathrm{mL}$ of trypsin in PBS for $10 \mathrm{~min}$ at $37^{\circ} \mathrm{C}$; Sample B-Two trypsin digestions: $2.5 \mu \mathrm{g} / \mathrm{mL}$ of trypsin in PBS for $10 \mathrm{~min}$ at $37^{\circ} \mathrm{C}$, and an additional trypsin $(1 \mu \mathrm{g} / \mathrm{mL})$ digestion overnight at $37^{\circ} \mathrm{C}$, after cell debris removal by centrifugation and filtration. 
3.2.2. Identification of Surface-Exposed Proteins Using Trypsin Digestion of Live B. cenocepacia J2315 Cells

The trypsin-generated peptides were analyzed by LC-MS/MS. Upon the validation of peptide spectral matches, it was possible to identify 1169 proteins. Considering that the B. cenocepacia J2315 genome harbors 7117 coding sequences (CDS), the surface-shaving method used retrieved $16.4 \%$ of the predicted CDSs. However, to avoid false-positive identification, we used a threshold score of $\geq 5$ unique peptides within a single protein, according to the recommendations of Higdon and Kolker (2007) [38]. Using this criterion, a total of 333 proteins were selected for the further bioinformatics analysis of subcellular localization with PSORTb and function analysis with Pfam (Table S3, Figure 4).

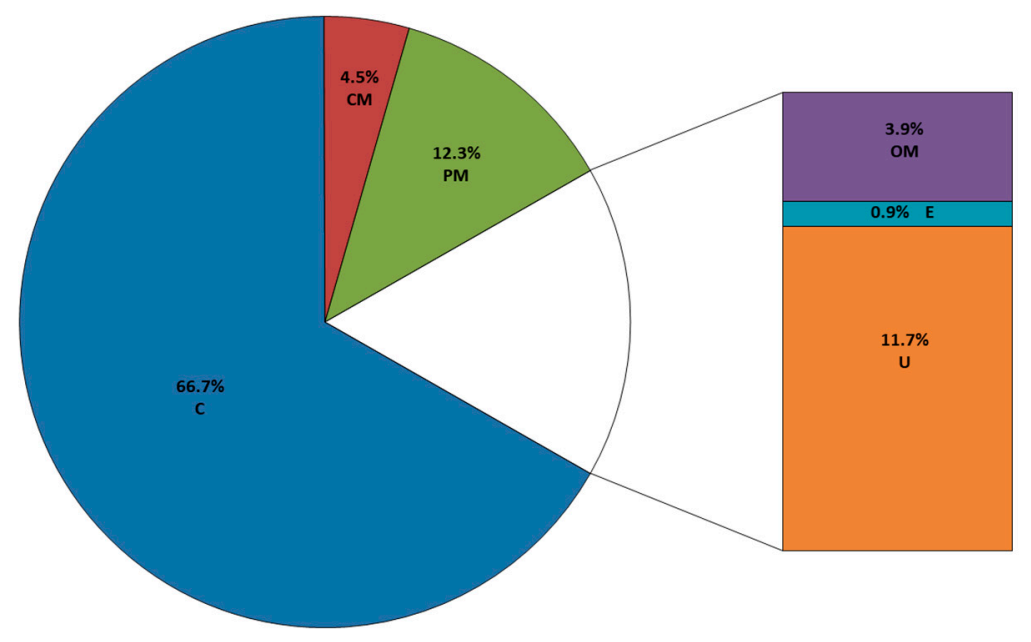

Figure 4. Percentage representation of the subcellular localization of the surface-shaving-identified proteins from B. cenocepacia $\mathrm{J} 2315$, as determined by PSORTb 3.0.2. The 333 proteins ( $\geq 5$ peptides within a single protein) were classified in the following categories: outer membrane (OM), extracellular (E), periplasm (PM), cytoplasmic membrane (CM), cytoplasm (C) and unknown (U).

A total of 55 predicted surface-exposed proteins (13 outer membrane proteins, 3 extracellular and 39 unknown) were identified (Table 2). These proteins were further analyzed using BepiPred 2.0 to study the probability of the exposed moieties being immunogenic (Table S4). A large fraction of the proteins identified had predicted intracellular subcellular localization (222 cytoplasmic proteins; 15 from the cytoplasmic membrane and 41 from the periplasm). However, around $63 \%$ of orthologues of these identified proteins (164 cytoplasmic proteins; seven from the cytoplasmic membrane and four from the periplasm) were previously reported to be intracellular/surface moonlighting proteins in other Gram-negative bacteria [39]. 
Table 2. Summary of surface-associated proteins identified in B. cenocepacia J2315 by using the "surface shaving" strategy followed by LC-MS/MS (threshold score: $\geq 5$ peptides). Their subcellular localization, associated biological functions, numbers of unique peptides identified and probabilities of containing predicted immunogenic epitopes are shown.

\begin{tabular}{|c|c|c|c|c|c|}
\hline ORF $^{1}$ & Description $^{1}$ & $\begin{array}{l}\text { Peptides Identified } \\
\text { (PSMs) }^{2}\end{array}$ & Subcellular Localization ${ }^{3}$ & Domains ${ }^{4}$ & $\begin{array}{l}\text { B-Cell Epitope Average } \\
\text { (Predicted Peptides) }^{5}\end{array}$ \\
\hline $\begin{array}{l}\text { BCAL1416 } \\
\text { (AlaS) }\end{array}$ & Alanyl-tRNA synthetase & $23(28)$ & $\mathrm{U}$ (Class 3) & $\begin{array}{l}\text { tRNA synthetases class II (A) (PF01411) } \\
\text { Threonyl and Alanyl tRNA synthetase second } \\
\text { additional domain (PF07973) } \\
\text { DHHA1 domain (PF02272) }\end{array}$ & $0.464(23)$ \\
\hline BCAM0965 (mdh) & Malate dehydrogenase & $17(29)$ & U (Class 3) & $\begin{array}{c}\text { Lactate/malate dehydrogenase, NAD binding } \\
\text { domain (PF00056) } \\
\text { Lactate/malate dehydrogenase, alpha/beta } \\
\text { C-terminal domain (PF02866) }\end{array}$ & $0.430(6)$ \\
\hline BCAL2736 & Isocitrate dehydrogenase & $17(25)$ & $\mathrm{U}($ Class 3$)$ & Isocitrate/isopropylmalate dehydrogenase (PF00180) & $0.460(8)$ \\
\hline BCAL3203 (TolB) & Translocation protein TolB & $17(22)$ & U (Class 3) & $\begin{array}{c}\text { TolB amino-terminal domain (PF04052) } \\
\text { WD40-like Beta Propeller Repeat (PF07676) }\end{array}$ & $0.454(9)$ \\
\hline BCAL2777 & $\begin{array}{c}\text { Putative } \\
\text { N-acetylmuramoyl-L-alanine } \\
\text { amidase }\end{array}$ & $14(15)$ & U (Class 3) & $\begin{array}{l}\text { AMIN domain (PF11741) } \\
\text { N-acetylmuramoyl-L-alanine amidase (PF01520) }\end{array}$ & $0.511(12)$ \\
\hline BCAL2956 & Hypothetical protein & $13(32)$ & $\mathrm{U}$ (Class 3) & $\begin{array}{c}\text { DUF2059 (PF09832) } \\
\text { Peptidase M1 N-terminal domain (PF17900) }\end{array}$ & $0.485(6)$ \\
\hline BCAL2993 (PepN) & Aminopeptidase $\mathrm{N}$ & $13(14)$ & $\mathrm{U}$ (Class 3) & $\begin{array}{c}\text { Peptidase family M1 domain (PF01433) } \\
\text { DUF3458, Ig-like fold (PF11940) } \\
\text { DUF3458_C, ARM repeats (PF17432) }\end{array}$ & $0.456(24)$ \\
\hline BCAL3311 (BcnA) & Secreted bacterial lipocalin & $12(22)$ & $\mathrm{E}$ (Class 1) & YceI-like domain (PF04264) & $0.455(3)$ \\
\hline BCAL1262 (CarB) & $\begin{array}{l}\text { Carbamoyl phosphate } \\
\text { synthase large subunit }\end{array}$ & $12(13)$ & U (Class 3) & $\begin{array}{c}\text { Carbamoyl-phosphate synthase L chain: ATP } \\
\text { binding domain (PF02786); } \\
\text { Oligomerization domain (PF02787) } \\
\text { MGS-like domain (PF02142) }\end{array}$ & $0.457(25)$ \\
\hline BCAM1931 & Putative porin & $11(15)$ & OM (Class 3) & Porin_4 (PF13609) & $0.503(10)$ \\
\hline BCAL0765 & Hypothetical protein & $11(12)$ & U (Class 3) & $\begin{array}{l}\text { ABC transporter substrate-binding } \\
\text { protein (PF04392) }\end{array}$ & $0.454(5)$ \\
\hline BCAL1961 & Hypothetical protein & $10(20)$ & $\mathrm{U}$ (Class 3) & Ankyrin repeats (PF12796) & $0.472(6)$ \\
\hline BCAM0906 & $\begin{array}{l}\text { Putative dienelactone } \\
\text { hydrolase family protein }\end{array}$ & $10(14)$ & $\mathrm{U}$ (Class 3) & Dienelactone hydrolase family (PF01738) & $0.471(7)$ \\
\hline BCAL2206 (PhaP) & Phasin-like protein & $10(13)$ & U (Class 3) & Phasin_2 protein (PF09361) & $0.482(5)$ \\
\hline
\end{tabular}


Table 2. Cont

\begin{tabular}{|c|c|c|c|c|c|}
\hline ORF $^{1}$ & Description $^{1}$ & $\begin{array}{c}\text { Peptides Identified } \\
\text { (PSMs) }^{2}\end{array}$ & Subcellular Localization ${ }^{3}$ & Domains ${ }^{4}$ & $\begin{array}{l}\text { B-Cell Epitope Average } \\
\text { (Predicted Peptides) }^{5}\end{array}$ \\
\hline BCАМ0043 & Hypothetical protein & $10(12)$ & U (Class 3) & $\begin{array}{c}\text { Phage late control gene D protein (PF05954) } \\
\text { T6SS_Vgr (PF13296) } \\
\text { DUF2345 (PF10106) }\end{array}$ & $0.494(12)$ \\
\hline BCAL0340 (BscM) & $\begin{array}{l}\text { Putative lipoprotein. Part of } \\
\text { the T6SS gene cluster }\end{array}$ & $9(13)$ & U (Class 3) & Tetratricopeptide repeat (PF14559) & $0.506(6)$ \\
\hline BCAL1493 & Putative exported protein & $9(12)$ & $\mathrm{U}$ (Class 3) & NlpB/DapX lipoprotein (PF06804) & $0.518(6)$ \\
\hline BCAL0305 & Hypothetical protein & $8(21)$ & U (Class 3) & MlaC protein (PF05494) & $0.480(7)$ \\
\hline BCAL1893 & Family M23 peptidase & $8(13)$ & OM (Class 3) & $\begin{array}{c}\text { LysM domain (PF014769) } \\
\text { Peptidase family M23 (PF01551) }\end{array}$ & $0.523(4)$ \\
\hline BCAL0151 & Putative lipoprotein & $8(12)$ & U (Class 3) & Periplasmic binding protein (PF13458) & $0.439(10)$ \\
\hline BCAL2934 (EtfA) & $\begin{array}{l}\text { Electron transfer flavoprotein } \\
\text { alpha-subunit }\end{array}$ & $8(10)$ & U (Class 3) & $\begin{array}{l}\text { Electron transfer flavoprotein domain (PF01012) } \\
\text { Electron transfer flavoprotein FAD-binding } \\
\text { domain (PF00766) }\end{array}$ & $0.443(3)$ \\
\hline BCAM1012 & Putative histone-like protein & $8(10)$ & $\mathrm{U}$ (Class 3) & Bacterial DNA-binding protein (PF00216) & $0.520(2)$ \\
\hline BCAM2827 & Hypothetical protein & $7(13)$ & $\mathrm{U}($ Class 3) & MlaC protein (PF05494) & $0.462(4)$ \\
\hline BCAS0667 & Uncharacterized protein & $7(9)$ & $\mathrm{U}$ (Class 3) & Phage late control gene D protein (PF05954) & $0.500(20)$ \\
\hline BCAL0020 & $\begin{array}{l}\text { Putative branched-chain } \\
\text { amino acid ABC transporter } \\
\text { periplasmic substrate } \\
\text { binding protein }\end{array}$ & $7(9)$ & U (Class 3) & Periplasmic binding protein (PF13458) & $0.442(8)$ \\
\hline BCAS0219 & Hypothetical protein & $7(8)$ & $\mathrm{U}$ (Class 3$)$ & $\begin{array}{l}\text { Outer membrane lipoprotein-sorting protein } \\
\text { (PF17131) }\end{array}$ & $0.461(7)$ \\
\hline BCAM2736 & Hypothetical protein & $7(8)$ & $\mathrm{U}$ (Class 3) & none & $0.534(0)$ \\
\hline BCAM1712 (PaaH) & $\begin{array}{l}\text { 3-hydroxy-acyl-CoA } \\
\text { dehydrogenase }\end{array}$ & $7(8)$ & U (Class 3) & $\begin{array}{c}\text { 3-hydroxyacyl-CoA dehydrogenase: NAD binding } \\
\text { domain (PF02737); } \\
\text { C-terminal domain (PF00725) } \\
\text { 3-hydroxybutyryl-CoA dehydrogenase reduced } \\
\text { Rossmann-fold domain (PF18321) }\end{array}$ & $0.443(7)$ \\
\hline BCAL2687 & Putative lipoprotein & $7(7)$ & U (Class 3) & Periplasmic binding protein (PF13458) & $0.438(7)$ \\
\hline
\end{tabular}


Table 2. Cont.

\begin{tabular}{|c|c|c|c|c|c|}
\hline ORF $^{1}$ & Description $^{1}$ & $\begin{array}{l}\text { Peptides Identified } \\
\text { (PSMs) }^{2}\end{array}$ & Subcellular Localization ${ }^{3}$ & Domains ${ }^{4}$ & $\begin{array}{l}\text { B-Cell Epitope Average } \\
\text { (Predicted Peptides) }^{5}\end{array}$ \\
\hline BCAL2946 (udg) & UDP-glucose dehydrogenase & $7(7)$ & $\mathrm{U}$ (Class 3) & $\begin{array}{c}\text { UDP-glucose/GDP-mannose dehydrogenase family: } \\
\text { NAD binding domain (PF03721); } \\
\text { Central domain (PF00984); } \\
\text { UDP binding domain (PF03720) }\end{array}$ & $0.447(11)$ \\
\hline BCAL2828 & Hypothetical protein & $6(11)$ & $\mathrm{U}$ (Class 3) & Carboxypeptidase regulatory-like domain (PF13620) & $0.468(3)$ \\
\hline BCAL3204 (Pal) & $\begin{array}{l}\text { Peptidoglycan-associated } \\
\text { lipoprotein }\end{array}$ & $6(9)$ & OM (Class 3) & OmpA family (PF00691) & $0.507(3)$ \\
\hline BCAS0147 & Hypothetical protein & $6(7)$ & $\mathrm{U}$ (Class 3) & Lactonase, 7-bladed beta-propeller (PF10282) & $0.463(12)$ \\
\hline BCAL3228 & Hypothetical protein & $6(7)$ & $\mathrm{U}$ (Class 3) & none & $0.516(3)$ \\
\hline BCAL2022 & PspA/IM30 family protein & $6(6)$ & OM (Class 3$)$ & PspA/IM30 family (PF04012) & $0.503(3)$ \\
\hline BCAL1985 & $\begin{array}{l}\text { Putative peptidylprolyl } \\
\text { isomerase }\end{array}$ & $6(6)$ & $\mathrm{OM}$ (Class 3) & PPIC-type PPIASE domain (PF13616) & $0.494(5)$ \\
\hline BCAL2083 (YaeT) & $\begin{array}{l}\text { Outer membrane protein } \\
\text { assembly factor YaeT }\end{array}$ & $6(6)$ & OM (Class 3) & $\begin{array}{c}\text { Surface antigen variable number repeat } \\
\text { POTRA (PF07244) } \\
\text { Omp85 (PF01103) }\end{array}$ & $0.488(19)$ \\
\hline BCAM0900 & Hypothetical protein & $6(6)$ & $\mathrm{U}$ (Class 3) & Peptidase propeptide and YPEB domain (PF13670) & $0.537(0)$ \\
\hline BCAL0377 & $\begin{array}{l}\text { Subfamily M24B } \\
\text { metalopeptidase }\end{array}$ & $6(6)$ & $\mathrm{U}$ (Class 3) & $\begin{array}{c}\text { Creatinase/prolidase N-terminal domain } \\
\text { (PF01321) (PF16189) } \\
\text { Metallopeptidase family M24 (PF00557) } \\
\text { C-terminal region of peptidase_M24 (PF16188) }\end{array}$ & $0.455(12)$ \\
\hline BCAM1833 (AcnB) & $\begin{array}{l}\text { Bifunctional aconitate } \\
\text { hydratase } \\
\text { 2/2-methylisocitrate } \\
\text { dehydratase }\end{array}$ & $6(6)$ & $\mathrm{U}$ (Class 3) & $\begin{array}{c}\text { Aconitate B, N-terminal domain (PF11791) } \\
\text { Aconitate hydratase 2, N-terminus (PF06434) } \\
\text { Aconitase family (PF00330) }\end{array}$ & $0.469(16)$ \\
\hline BCAL0804 & Hypothetical protein & $6(6)$ & $\mathrm{U}$ (Class 3$)$ & $\begin{array}{l}\text { Tetratricopeptide repeat (PF14559) } \\
\text { Tetratricopeptide repeat (PF13432) }\end{array}$ & $0.455(20)$ \\
\hline BCAM2761 (CblA) & Giant cable pilus & $5(12)$ & $\mathrm{E}$ (Class 3) & CS1 type fimbrial major subunit (PF04449) & $0.501(2)$ \\
\hline BCAL2645 & $\begin{array}{l}\text { Putative OmpA } \\
\text { family protein }\end{array}$ & $5(11)$ & OM (Class 3) & $\begin{array}{l}\text { YMGG-like Gly-zipper (PF13441) } \\
\text { OmpA family (PF00691) }\end{array}$ & $0.502(4)$ \\
\hline BCAL1288 & Family M23 peptidase & $5(9)$ & OM (Class 3) & $\begin{array}{l}\text { LysM domain (PF01476) } \\
\text { Peptidase family M23 (PF01551) }\end{array}$ & $0.513(5)$ \\
\hline BCAL2738 & Hypothetical protein & $5(7)$ & $\mathrm{U}$ (Class 3) & DUF192 (PF02643) & $0.461(4)$ \\
\hline BCAL0389 (DsbC) & $\begin{array}{l}\text { Thiol:disulfide } \\
\text { interchange protein }\end{array}$ & $5(7)$ & $\mathrm{U}$ (Class 3) & $\begin{array}{l}\text { Disulfide bond isomerase protein } \\
\text { N-terminus (PF10411) } \\
\text { Thioredoxin-like domain (PF13098) }\end{array}$ & $0.481(3)$ \\
\hline
\end{tabular}


Table 2. Cont.

\begin{tabular}{|c|c|c|c|c|c|}
\hline ORF $^{1}$ & Description $^{1}$ & $\begin{array}{l}\text { Peptides Identified } \\
\text { (PSMs) }^{2}\end{array}$ & Subcellular Localization ${ }^{3}$ & Domains $^{4}$ & $\begin{array}{l}\text { B-Cell Epitope Average } \\
\text { (Predicted Peptides) }^{5}\end{array}$ \\
\hline BCAL3035 (TrxB) & Thioredoxin reductase & $5(6)$ & U (Class 3) & $\begin{array}{l}\text { Pyridine nucleotide-disulphide oxidoreductase } \\
\text { (PF07992) }\end{array}$ & $0.449(6)$ \\
\hline BCAL1881 (BamB) & $\begin{array}{l}\text { Outer membrane protein } \\
\text { assembly factor BamB }\end{array}$ & $5(5)$ & OM (Class 3) & PQQ-like domain (PF13360) & $0.444(8)$ \\
\hline BCAM2549 (OpcM) & $\begin{array}{l}\text { Multidrug efflux system outer } \\
\text { membrane protein }\end{array}$ & $5(5)$ & OM (Class 1) & Outer membrane efflux protein (PF02321) & $0.521(11)$ \\
\hline BCAL0304 & VacJ-like lipoprotein & $5(5)$ & OM (Class 3) & MlaA lipoprotein (PF04333) & $0.469(4)$ \\
\hline $\begin{array}{l}\text { BCAL0342 } \\
\text { (BcsK) }\end{array}$ & $\begin{array}{l}\text { Putative type VI secretion } \\
\text { system protein TssC }\end{array}$ & $5(5)$ & OM (Class 3) & $\begin{array}{l}\text { EvpB/VC_A0108, tail sheath N-terminal domain } \\
\text { (PF05943) }\end{array}$ & $0.472(15)$ \\
\hline BCAL0273 (СуaY) & Frataxin-like protein & $5(5)$ & U (Class 3) & Frataxin-like domain (PF01491) & $0.465(2)$ \\
\hline
\end{tabular}

${ }^{1}$ Burkholderia Genome Database [30,40]. ${ }^{2}$ Number of unique peptides identified using surface shaving with trypsin and LC-MS/MS analysis. PSMs-peptide-spectrum matches.

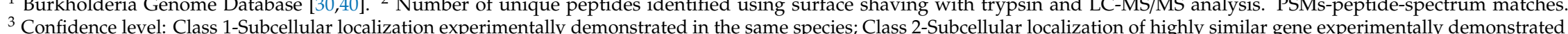
in another organism OR a paralog experimentally demonstrated in the same organism. BLAST Expect value of $10 \mathrm{e}^{-10}$ for query within $80-120 \%$ of subject length; Class 3 -Subcellular localization computationally predicted by PSORTb V3.0 [32]. Abbreviations: OM-outer membrane; E-extracellular; U-unknown. ${ }^{4}$ Pfam Database [31,41]. ${ }^{5}$. BepiPred-2.0 server [35,42]. Threshold of 0.5 used. Peptides shorter than 5 or larger than 25 amino acids were not considered. 


\subsection{Characterization of B. cenocepacia bcal2022 and bcal2645 Proteins' Immunoreactivity}

In order to validate the results from the LC-MS/MS identification of surface-exposed proteins and bioinformatics analysis of putative immunogenic proteins, we selected three proteins identified by the surfomics approach and with a high probability of comprising surface-exposed immunogenic peptides by bioinformatics for further analysis. These include the outer membrane protein A (OmpA)-like proteins BCAL2958 and BCAL2645, and BCAL2022, a phage-shock protein A (PspA)-like protein (Table 3).

Table 3. Selected surface-associated proteins identified in B. cenocepacia J2315 by using the "surface shaving" strategy followed by LC-MS/MS (threshold score: $\geq 5$ peptides) and their predicted B-cell epitopes. The peptides identified by the surface-shaving approach and predicted as B-cell epitopes are shown in bold.

\begin{tabular}{|c|c|c|c|}
\hline ORF & Description & Peptides Identified $^{1}$ & Predicted B-Cell Epitopes ${ }^{2}$ \\
\hline BCAL2958 & $\begin{array}{l}\text { OmpA family } \\
\text { protein }\end{array}$ & $\begin{array}{c}{ }^{93} \text { ITYQADALFDFDK }^{105} \\
{ }^{93} \text { ITYQADALFDFDKATLKPLGK }^{113} \\
{ }^{114} \text { QKLDELASK }^{122} \\
{ }^{116} \text { LDELASK }^{122} \\
{ }^{123} \text { IEGMNTEVVVATGYTDR }^{139} \\
{ }^{203} \text { RVEVEVVGTQQVQK }^{216} \\
{ }^{204} \text { VEVEVVGTQQVQK }^{216}\end{array}$ & $\begin{array}{c}{ }^{101} \text { FDFDKATLKPLGKQ }^{114} \\
{ }^{139} \text { RIGSDKYNDRL }^{149} \\
{ }^{211} \text { TQQVQKTTV }^{219}\end{array}$ \\
\hline BCAL2645 & $\begin{array}{l}\text { OmpA family } \\
\text { protein }\end{array}$ & $\begin{array}{c}{ }^{79} \text { LAPSAAQTGTQVTEQPDGSLK }^{99} \\
{ }^{161} \text { AQSVVNALVQR } \\
{ }^{171} \\
{ }^{178} \text { LSAQGMGASNPIADNATEAGR }^{198} \\
{ }^{203} \text { RVEIYLR }^{209} \\
{ }^{204} \text { VEIYLR }^{209}\end{array}$ & $\begin{array}{c}{ }^{88} \text { TQVTEQ }^{93} \\
{ }^{109} \text { ATNQYAITPA }^{118} \\
{ }^{145} \text { DSTGSAQLNQTL }^{156} \\
{ }^{183} \text { MGASNPIADNATEAGRAQN }^{201}\end{array}$ \\
\hline BCAL2022 & $\begin{array}{l}\text { PspA/IM30 } \\
\text { family protein }\end{array}$ & $\begin{array}{c}{ }^{13} \text { GLLNDAADSVQDPSR }^{27} \\
{ }^{35} \text { ELDDSIGR }^{42} \\
{ }^{43} \text { AENSLIEIEAQVATQR }^{58} \\
{ }^{78} \text { ALQGGDEALAR }^{88} \\
{ }^{89} \text { EALAAQSNAEAER }^{101} \\
{ }^{150} \text { DVAASALGGIGGK }^{162}\end{array}$ & $\begin{array}{c}{ }^{20} \text { DSVQDPSRD }^{28} \\
{ }^{156} \text { LGGIGGKNLSEDFQKLEDK }^{174} \\
{ }^{215} \text { AALKKQLD }^{222}\end{array}$ \\
\hline
\end{tabular}

${ }^{1}$ Peptides identified using surface-shaving with trypsin and LC-MS/MS analysis. ${ }^{2}$ BepiPred-2.0 server [35,42]. Threshold of 0.5 used. Peptides shorter than 5 or larger than 25 amino acids were not considered.

In order to produce the proteins BCAL2645 and BCAL2022, the BCAL2645 and BCAL2022 genes were cloned into the expression vector pET23a+ under the control of the T7 promoter. Then, the overexpression of the proteins was achieved in E. coli as $6 \times$ His-tagged derivatives by induction with IPTG. The recombinant proteins were then purified to homogeneity by nickel affinity chromatography (Figure 5A). To test the immunoreactivity of the proteins BCAL2645 and BCAL2022, the purified fraction of each of the proteins was used for the detection of IgG antibodies against each protein in two serum samples from CF patients with a clinical record of Bcc infection (Figure 5A). BCAL2958 was used as positive control, and bovine serum albumin fraction V (BSA) was used as a negative control. Similarly to BCAL2958, the BCAL2465 protein exhibited a strong immunoreactivity against the tested sera from the CF patients infected with Bcc, indicating that the immunological systems of the CF patients were exposed to this protein during the infection and developed antibodies against it, therefore showing it to be a good candidate for immunotherapies. On the other hand, the BCAL2022 protein was only immunoreactive with one of the serum samples tested (Figure 5A) and therefore was not used in ELISA experiments. These results suggest that although the gene encoding the BCAL2022 protein is highly conserved in Bcc [19], the expression and surface-exposure of the protein is not a common trait of the Bcc bacteria during the infection of CF patients. No reactivity of the tested proteins was observed when using samples of a pool of sera from healthy individuals (Figure 5B). 
A

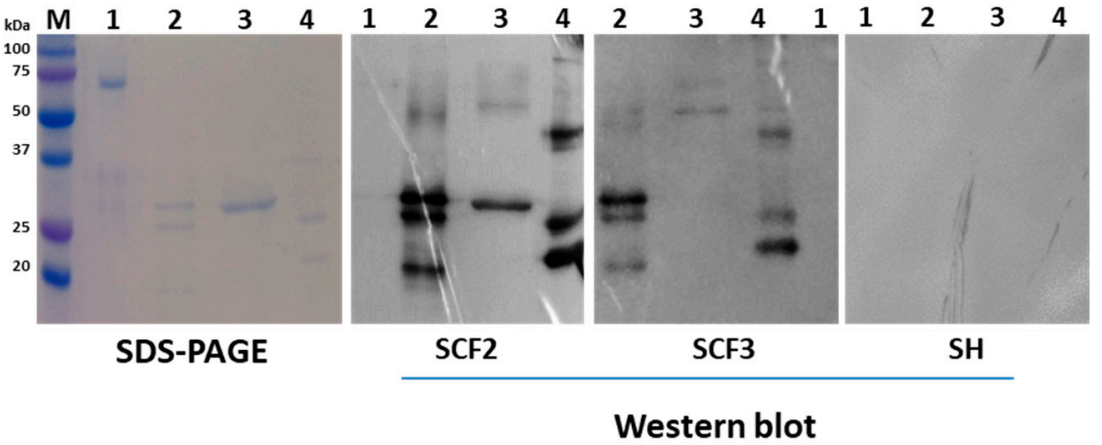

B

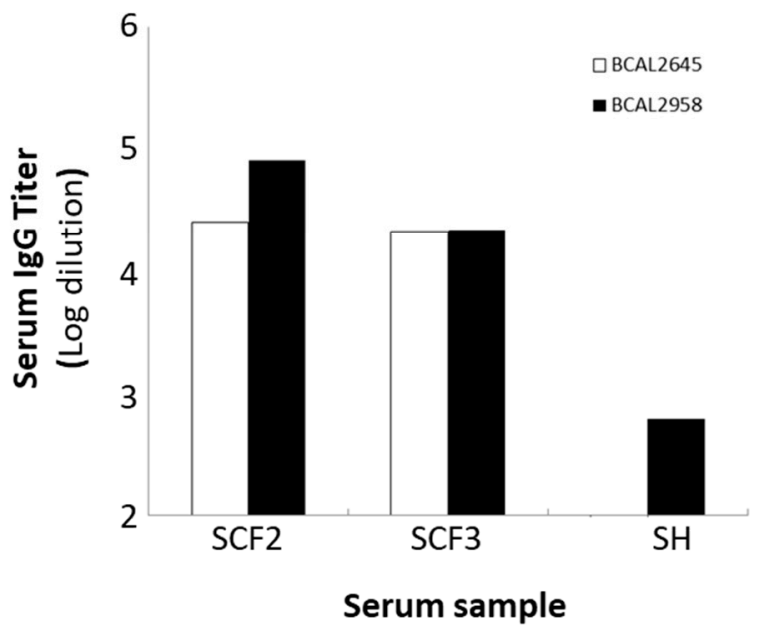

Figure 5. A-SDS-PAGE and Western blot of the purified recombinant proteins BCAL2022, BCAL2645 and BCAL2958 from B. cenocepacia J2315 probed with the human serum samples SCF2 and SCF3 from CF patients with positive cultures of Bcc bacteria or a pool of human serum samples from healthy donors (SH). Lanes: M-Precision Plus ProteinTM DualXtra Standard (BIORAD); 1-BSA; 2-purified recombinant protein BCAL2958; 3-purified recombinant protein BCAL2022; 4-purified recombinant protein BCAL2645; B - levels of IgG antibody against BCAL2645 and BCAL2958 proteins present in serum samples from CF patients with clinical history of BcC infection (SCF2 and 3) and in healthy individuals (SH). Serum antibody concentrations were defined as endpoint titers and were calculated as the reciprocal of the highest serum dilution producing an $\mathrm{OD}_{450}$ above the cut-off value. The cut-off value was determined as the mean $\mathrm{OD}_{450}$ negative control plus 3 standard deviations. Titers of $\geq 700$ and $\geq 100$ were considered as positive for BCAL2958 and BCAL2645, respectively. The IgG titer data for BCAL2958 were previously obtained in [26].

Analysis of the BCAL2958, BCAL2645 and BCAL2022 amino acid sequences using the ProtParam program revealed that these proteins have predicted molecular weights of 23.9, 21.6 and 24.3 kDa, respectively. After SDS-PAGE, at least three different-molecular-weight forms of the protein BCAL2958 and two such of BCAL2645 were apparent (Figure 5A). The multiple bands most probably resulted from the different stages of processing and translocation of the proteins from the cytoplasm to the outer membrane, as previously reported for the BCAL2958 protein and for other OmpA-like proteins [26]. In the case of BCAL2958, the first two forms with higher molecular masses were described to correspond to the native pre-protein with a $6 \times$ His-tag containing the signal peptide, and the mature protein with a $6 \times$ His-tag without the signal peptide, respectively [26]. The serum samples from CF patients with Bcc infection records presented high antibody titers against BCAL2645 and BCAL2958, reinforcing these two proteins as interesting components for a vaccine to combat Bcc infections. 


\section{Discussion}

A strategy combining bioinformatics and experimental approaches envisaging the identification of surface-exposed and immunogenic proteins of the epidemic strain B. cenocepacia $\mathrm{J} 2315$ as a representative of Bcc was pursued in this work. The strain was involved in documented patient-to-patient transmission episodes, resulting in several deaths among CF patients [25], and its genome sequence is publicly available [43]. Bcc species are intrinsically resistant to currently available antibiotics including penicillins, narrow-spectrum cephalosporins, aminoglycosides, and polymyxins, and effective strategies for eradicating chronic Bcc infections are lacking [44]. In this context, the development of protective vaccines against Bcc infections becomes highly attractive. To date, no such vaccine is available and only a few studies have been performed envisaging the identification of Bcc immunogenic proteins with the potential to originate a protective and lasting immune response [12-14,19,45,46].

Among all the proteins of a pathogen, surface-exposed proteins are the most likely to be involved in the initial steps of pathogen-host interactions and thus to induce immunological responses by the host, being highly attractive for the development of protective vaccines. The bioinformatics survey performed in the present work allowed the identification, within the genome sequence of $B$. cenocepacia J2315, of 263 proteins putatively surface-exposed (including outer membrane and extracellular proteins), 143 of them predicted to contain B-cell epitopes. In order to validate our data, an experimental approach was performed based on the "shaving" approach developed by Rodríguez-Ortega [27], followed by the LC-MS/MS identification of trypsin-digested peptides. To the best of our knowledge, this is the first report of the application of the "surface shaving" technique to identify surface-exposed proteins using live cells of a Bcc member.

Although a total of 263 proteins were predicted as surface-exposed proteins and 143 were bioinformatically predicted as potentially immunogenic, the number of surface-exposed proteins predicted as immunogenic identified by the "shaving" approach was only 16 . These differences reinforce the importance of using combined bioinformatics and experimental approaches, since proteins encoded in genomes are not necessarily expressed under specific conditions. Furthermore, genomes often contain incorrect annotations and bioinformatics predictions often fail [47].

In order to identify proteins that were specifically associated with the infection environment, B. cenocepacia J2315 cells were cultivated in ASM medium, to mimic the conditions found in the CF lungs. The importance of using culture media mimicking the conditions of infection was highlighted by Liu et al., who found a total of 121 outer membrane proteins produced by B. cenocepacia strain Y10 after cultivation in different media, 37 proteins being uniquely identified when the cells were cultivated in ASM [48]. Wolden and colleagues also performed the cell-shaving technique with Staphylococcus haemolyticus after the bacterium's cultivation in the presence of keratinocytes, highlighting the importance of the use of the technique after host-microbe interaction [49].

In addition to the expected surface-exposed proteins, we have also identified cytoplasmic proteins, most probably resulting from cell lysis, estimated to have occurred in about $20 \%$ of the cells in the optimized buffer. Variable and, in some cases, much more extensive lysis have also been reported for various Gram-positive bacteria, expected to be more resistant to mechanical stress [17,50]. In the case of Gram-negative bacteria, the amount of predicted cytoplasmic proteins identified using the surface-shaving approach can range from 10 to $62 \%$ [17]. Although some fraction of these predicted cytoplasmic proteins can be the result of cell lysis, they can be also proteins that reach the bacterial surface by non-canonical pathways or can be cytoplasmic proteins that are released by the shedding of membrane-vesicle structures containing these proteins [17].

In fact, a fraction of around $63 \%$ of the predicted intracellular identified proteins (164 cytoplasmic proteins; seven from the cytoplasmic membrane and four from the periplasm) includes proteins described as moonlighting due to their localization-dependent functions in the cell in other Gram-negative bacteria [39]. Moonlighting proteins can have different functions in different cellular locations, playing important roles in bacterial virulence and host-pathogen interactions [51]. We also 
do not exclude that some cytoplasmic proteins identified might result from their secretion as part of the cargo of outer-membrane vesicles formed by B. cenocepacia J2315.

Regardless of some contamination with cytoplasmic proteins, the shaving approach was successfully used, allowing the identification of proteins predicted as immunogenic, and for three of them, we have confirmed their reactivity with sera from two CF patients with records of infection by Bcc [19]. While the BCAL2958 protein was already cloned and available in our laboratory [26], the cloning, overexpression and purification of the BCAL2645 and BCAL2022 proteins is here reported for the first time. The B. cenocepacia proteins BCAL2958 and BCAL2645 are members of the OmpA-like family of proteins, demonstrated for other pathogens as abundant in outer membranes, highly immunogenic and with the capability of eliciting a strong host immune response [52,53]. OmpA-like proteins have also been found to be important in maintaining the integrity of the outer membrane and to be involved in pathogenesis [52,53]. The protein BCAL2958 was previously characterized by our research group as an immunogenic protein and was used in this work as a positive control [26]. More recently, the PspA-like protein BCAL2022 was also identified by immunoproteomics in a study from our research group [19]. PspA-like proteins were previously shown to play a role in the stress response, being important for the survival and virulence of several bacterial pathogens [54]. In B. pseudomallei, PspA was found to be important for intracellular survival in a macrophage cell line [55]. Although the serum samples used are quite limited due to the difficulties in gathering samples from CF patients infected with $\mathrm{Bcc}$, the positive reactivity with the selected proteins is here demonstrated. This work is expected to pave the way for future studies including larger CF serum samples from patients infected with different Bcc species, in order to evaluate the universality of these proteins, as well as of others, to be identified as immunogenic proteins, towards the development of a Bcc protective vaccine. Bcc share a relatively high degree of conservation with other pathogenic $B$. species such as $B$. mallei and B. pseudomallei. Therefore, the exploitation of common immunogenic proteins would be useful for the development of a broad-spectrum vaccine towards pathogenic members of the $B$. genus.

\section{Conclusions}

The surface-protein identification of live Bcc bacteria, after cell growth in conditions that mimic the CF lung, through a "shaving" approach and further bioinformatics analysis of the immunogenicity of the surface-exposed identified peptides, was for the first time demonstrated to be a reliable method for selecting vaccine candidates or even for the development of new immunodiagnostic tools. The present work was the first step in the optimization of the surface-shaving methodology for Bcc bacteria. In this work, we were able to identify 333 surface-associated proteins, 16 of them being predicted by PSORTb as surface-exposed proteins, 39 as unknown and 175 proteins with intracellular predicted location but previously described as moonlighting proteins in other bacterial species. Three of these proteins, BCAL2958, BCAL2645 and BCAL2022, were validated by Western blotting as immunogenic using serum samples from Bcc-infected CF patients. However, to develop a vaccine able to protect against a broader range of strains/species of Bcc bacteria, the immunogenic and surface-exposed proteins that are conserved and more expressed under conditions that mimic the $\mathrm{CF}$ lung have to be identified. Therefore, the surfomes of strains from different Bcc species should be compared for the selection of a panel of vaccine candidates with broader characteristics. The role of the surface-exposed proteins here identified and their exposed peptides in the interaction with the host will be also interesting to study.

Supplementary Materials: The following are available online at http://www.mdpi.com/2076-393X/8/3/509/s1, Table S1: Predicted outer membrane proteins encoded within the genome of Burkholderia cenocepacia J2315. Table S2: Predicted extracellular proteins encoded within the genome of Burkholderia cenocepacia J2315. Table S3: Proteins identified in Burkholderia cenocepacia J2315 by using the "surface shaving" strategy followed by LC-MS/MS (threshold score: $\geq 5$ peptides). Table S4: Predicted surface-exposed proteins identified in B. cenocepacia J2315 by using the "surface shaving" strategy followed by LC-MS/MS (threshold score: $\geq 5$ peptides) and their predicted B-cell epitopes. 
Author Contributions: Conceptualization, S.A.S. and J.H.L.; methodology, S.A.S., A.M.M.S., M.M. and M.J.R.-O.; writing-original draft preparation, S.A.S. and A.M.M.S.; writing-review and editing, J.H.L., S.A.S. and M.J.R.-O.; supervision, J.H.L. and S.A.S.; project administration, J.H.L. and S.A.S.; funding acquisition, J.H.L. All authors have read and agreed to the published version of the manuscript.

Funding: This research was funded by FCT through project PTDC/BIA-MIC/1615/2014 and iBB through project UIDB/04565/2020, Programa Operacional Regional de Lisboa 2020 (Project N. 007317).

Acknowledgments: Proteomic analysis was performed at the Proteomics Facility, SCAI (Central Facilities for Research Support, University of Córdoba). The authors acknowledge funding from iBB-Institute for Bioengineering and Biosciences through project UIDB/04565/2020. The authors also acknowledge FCT for PhD fellowships to AMMS (PhD Program in Applied and Environmental Microbiology, PD/BD/150420/2019).

Conflicts of Interest: The authors declare no conflict of interest. The funders had no role in the design of the study; in the collection, analyses or interpretation of data; in the writing of the manuscript; or in the decision to publish the results.

\section{References}

1. De Smet, B.; Mayo, M.; Peeters, C.; Zlosnik, J.E.A.; Spilker, T.; Hird, T.J.; Li Puma, J.J.; Kidd, T.J.; Kaestli, M.; Ginther, J.L.; et al. Burkholderia stagnalis sp. nov. and Burkholderia territorii sp. nov., two novel Burkholderia cepacia complex species from environmental and human sources. Int. J. Syst. Evol. Microbiol. 2015, 65, 2265-2271. [CrossRef] [PubMed]

2. Weber, C.F.; King, G.M. Volcanic soils as sources of novel CO-oxidizing Paraburkholderia and Burkholderia: Paraburkholderia hiiakae sp. nov., Paraburkholderia metrosideri sp. nov., Paraburkholderia paradisi sp. nov., Paraburkholderia peleae. Front. Microbiol. 2017, 8, 1-10. [CrossRef] [PubMed]

3. Martina, P.; Leguizamon, M.; Prieto, C.I.; Sousa, S.A.; Montanaro, P.; Draghi, W.O.; Stämmler, M.; Bettiol, M.; de Carvalho, C.C.C.R.; Palau, J.; et al. Burkholderia puraquae sp. nov., a novel species of the Burkholderia cepacia complex isolated from hospital settings and agricultural soils. Int. J. Syst. Evol. Microbiol. 2018, 68, 14-20. [CrossRef] [PubMed]

4. Tavares, M.; Kozak, M.; Balola, A.; Sá-Correia, I. Burkholderia cepacia complex bacteria: A feared contamination risk in water-based pharmaceutical products. Clin. Microbiol. Rev. 2020, 33, e00139-19. [CrossRef] [PubMed]

5. Leitão, J.H.; Sousa, S.A.; Ferreira, A.S.; Ramos, C.G.; Silva, I.N.; Moreira, L.M. Pathogenicity, virulence factors, and strategies to fight against Burkholderia cepacia complex pathogens and related species. Appl. Microbiol. Biotechnol. 2010, 87, 31-40. [CrossRef] [PubMed]

6. Isles, A.; Maclusky, I.; Corey, M.; Gold, R.; Prober, C.; Fleming, P.; Levison, H. Pseudomonas cepacia infection in cystic fibrosis: An emerging problem. J. Pediatr. 1984, 104, 206-210. [CrossRef]

7. Leitão, J.H.; Sousa, S.A.; Cunha, M.V.; Salgado, M.J.; Melo-Cristino, J.; Barreto, M.C.; Sá-Correia, I. Variation of the antimicrobial susceptibility profiles of Burkholderia cepacia complex clonal isolates obtained from chronically infected cystic fibrosis patients: A five-year survey in the major Portuguese treatment center. Eur. J. Clin. Microbiol. Infect. Dis. 2008, 27, 1101-1111. [CrossRef] [PubMed]

8. Scoffone, V.C.; Chiarelli, L.R.; Trespidi, G.; Mentasti, M.; Riccardi, G.; Buroni, S. Burkholderia cenocepacia infections in cystic fibrosis patients: Drug resistance and therapeutic approaches. Front. Microbiol. 2017, 8, 1592. [CrossRef] [PubMed]

9. Sousa, S.A.; Feliciano, J.R.; Pita, T.; Guerreiro, S.I.; Leitão, J.H. Burkholderia cepacia Complex Regulation of Virulence Gene Expression: A Review. Genes 2017, 8, 43. [CrossRef] [PubMed]

10. Lyczak, J.B.; Cannon, C.L.; Pier, G.B. Lung Infections Associated with Cystic Fibrosis Lung Infections Associated with Cystic Fibrosis. Clin. Microbiol. Rev. 2002, 15, 194-222. [CrossRef]

11. Regan, K.; Jayesh, B. Eradication therapy for Burkholderia cepacia complex in people with cystic fibrosis. Cochrane Database Syst. Rev. 2016, 11, CD009876. [CrossRef] [PubMed]

12. Sousa, S.; Seixas, A.; Leitão, J. Postgenomic Approaches and Bioinformatics Tools to Advance the Development of Vaccines against Bacteria of the Burkholderia cepacia Complex. Vaccines 2018, 6, 34. [CrossRef] [PubMed]

13. Scoffone, V.C.; Barbieri, G.; Buroni, S.; Scarselli, M.; Pizza, M.; Rappuoli, R.; Riccardi, G. Vaccines to Overcome Antibiotic Resistance: The Challenge of Burkholderia cenocepacia. Trends Microbiol. 2020, 28, 315-326. [CrossRef] [PubMed] 
14. McClean, S.; Healy, M.E.; Collins, C.; Carberry, S.; O'Shaughnessy, L.; Dennehy, R.; Adams, Á.; Kennelly, H.; Corbett, J.M.; Carty, F.; et al. Linocin and OmpW Are Involved in Attachment of the Cystic Fibrosis-Associated Pathogen Burkholderia cepacia Complex to Lung Epithelial Cells and Protect Mice against Infection. Infect. Immun. 2016, 84, 1424-1437. [CrossRef] [PubMed]

15. Pradenas, G.; Ross, B.; Torres, A. Burkholderia cepacia Complex Vaccines: Where Do We Go from here? Vaccines 2016, 4, 10. [CrossRef] [PubMed]

16. Grandi, G. Antibacterial vaccine design using genomics and proteomics. Trends Biotechnol. 2001, 19, 181-188. [CrossRef]

17. Olaya-Abril, A.; Jiménez-Munguía, I.; Gómez-Gascón, L.; Rodríguez-Ortega, M.J. Surfomics: Shaving live organisms for a fast proteomic identification of surface proteins. J. Proteomics 2014, 97, 164-176. [CrossRef]

18. Rabilloud, T. Membrane proteins and proteomics: Love is possible, but so difficult. Electrophoresis 2009, 30, 174-180. [CrossRef]

19. Sousa, S.A.; Soares-Castro, P.; Seixas, A.M.M.; Feliciano, J.R.; Balugas, B.; Barreto, C.; Pereira, L.; Santos, P.M.; Leitão, J.H. New insights into the immunoproteome of B. cenocepacia J2315 using serum samples from cystic fibrosis patients. N. Biotechnol. 2020, 54, 62-70. [CrossRef]

20. Walters, M.S.; Mobley, H.L.T. Identification of uropathogenic Escherichia coli surface proteins by shotgun proteomics. J. Microbiol. Methods 2009, 78, 131-135. [CrossRef]

21. Braconi, D.; Amato, L.; Bernardini, G.; Arena, S.; Orlandini, M.; Scaloni, A.; Santucci, A. Surfome analysis of a wild-type wine Saccharomyces cerevisiae strain. Food Microbiol. 2011, 28, 1220-1230. [CrossRef] [PubMed]

22. Castro-Borges, W.; Dowle, A.; Curwen, R.S.; Thomas-Oates, J.; Wilson, R.A. Enzymatic shaving of the tegument surface of live schistosomes for proteomic analysis: A rational approach to select vaccine candidates. PLoS Negl. Trop. Dis. 2011, 5, e993. [CrossRef] [PubMed]

23. Worlitzsch, D.; Tarran, R.; Ulrich, M.; Schwab, U.; Cekici, A.; Meyer, K.C.; Birrer, P.; Bellon, G.; Berger, J.; Weiss, T.; et al. Effects of reduced mucus oxygen concentration in airway Pseudomonas infections of cystic fibrosis patients. J. Clin. Investig. 2002, 109, 317-325. [CrossRef] [PubMed]

24. Sass, A.M.; Schmerk, C.; Agnoli, K.; Norville, P.J.; Eberl, L.; Valvano, M.A.; Mahenthiralingam, E. The unexpected discovery of a novel low-oxygen-activated locus for the anoxic persistence of Burkholderia cenocepacia. ISME J. 2013, 14, 1-14. [CrossRef] [PubMed]

25. Govan, J.R.; Deretic, V. Microbial pathogenesis in cystic fibrosis: Mucoid Pseudomonas aeruginosa and Burkholderia cepacia. Microbiol. Rev. 1996, 60, 539-574. [CrossRef] [PubMed]

26. Sousa, S.A.; Morad, M.; Feliciano, J.R.; Pita, T.; Nady, S.; El-Hennamy, R.E.; Abdel-Rahman, M.; Cavaco, J.; Pereira, L.; Barreto, C.; et al. The Burkholderia cenocepacia OmpA-like protein BCAL2958: Identification, characterization, and detection of anti-BCAL2958 antibodies in serum from B. cepacia complex-infected Cystic Fibrosis patients. AMB Express 2016, 6, 1-14. [CrossRef]

27. Rodríguez-Ortega, M.J. 'Shaving' Live Bacterial Cells with Proteases for Proteomic Analysis of Surface Proteins. In Methods in Molecular Biology (Clifton, N.J.); Humana Press: Totowa, NJ, USA, 2018; Volume 1722, pp. 21-29.

28. Sriramulu, D.D.; Lünsdorf, H.; Lam, J.S.; Römling, U. Microcolony formation: A novel biofilm model of Pseudomonas aeruginosa for the cystic fibrosis lung. J. Med. Microbiol. 2005, 54, 667-676. [CrossRef]

29. Chevallet, M.; Luche, S.; Rabilloud, T. Silver staining of proteins in polyacrylamide gels. Nat. Protoc. 2006, 1, 1852-1858. [CrossRef]

30. Winsor, G.L.; Khaira, B.; Van Rossum, T.; Lo, R.; Whiteside, M.D.; Brinkman, F.S.L. The Burkholderia Genome Database: Facilitating flexible queries and comparative analyses. Bioinformatics 2008, 24, 2803-2804. [CrossRef]

31. El-Gebali, S.; Mistry, J.; Bateman, A.; Eddy, S.R.; Luciani, A.; Potter, S.C.; Qureshi, M.; Richardson, L.J.; Salazar, G.A.; Smart, A.; et al. The Pfam protein families database in 2019. Nucleic Acids Res. 2019, 47, D427-D432. [CrossRef]

32. Yu, N.Y.; Wagner, J.R.; Laird, M.R.; Melli, G.; Rey, S.; Lo, R.; Dao, P.; Sahinalp, S.C.; Ester, M.; Foster, L.J.; et al. PSORTb 3.0: Improved protein subcellular localization prediction with refined localization subcategories and predictive capabilities for all prokaryotes. Bioinformatics 2010, 26, 1608-1615. [CrossRef] [PubMed] 
33. Green, M.R.; Sambrook, J. Molecular Cloning: A Laboratory Manual; Cold Spring Harbor Laboratory Press: New York, NY, USA, 2012.

34. Burkholderia cenocepacia-Wellcome Sanger Institute. Available online: https://www.sanger.ac.uk/resources/ downloads/bacteria/burkholderia-cenocepacia.html (accessed on 30 July 2020).

35. Jespersen, M.C.; Peters, B.; Nielsen, M.; Marcatili, P. BepiPred-2.0: Improving sequence-based B-cell epitope prediction using conformational epitopes. Nucleic Acids Res. 2017, 45, W24-W29. [CrossRef] [PubMed]

36. Sharon, J.; Rynkiewicz, M.J.; Lu, Z.; Yang, C.-Y. Discovery of protective B-cell epitopes for development of antimicrobial vaccines and antibody therapeutics. Immunology 2014, 142, 1-23. [CrossRef] [PubMed]

37. Olaya-Abril, A.; Gómez-Gascón, L.; Jiménez-Munguía, I.; Obando, I.; Rodríguez-Ortega, M.J. Another turn of the screw in shaving Gram-positive bacteria: Optimization of proteomics surface protein identification in Streptococcus pneumoniae. J. Proteomics 2012, 75, 3733-3746. [CrossRef] [PubMed]

38. Higdon, R.; Kolker, E. A predictive model for identifying proteins by a single peptide match. Bioinformatics 2007, 23, 277-280. [CrossRef]

39. Mani, M.; Chen, C.; Amblee, V.; Liu, H.; Mathur, T.; Zwicke, G.; Zabad, S.; Patel, B.; Thakkar, J.; Jeffery, C.J. MoonProt: A database for proteins that are known to moonlight. Nucleic Acids Res. 2014, 43, 277-282. [CrossRef] [PubMed]

40. The Burkholderia Genome Database. Available online: https://www.burkholderia.com/ (accessed on 30 July 2020).

41. Pfam Database. Available online: http://pfam.xfam.org/ (accessed on 30 July 2020).

42. BepiPred 2.0 Server. Available online: http://tools.iedb.org/bcell/ (accessed on 30 July 2020).

43. Holden, M.T.G.; Seth-Smith, H.M.B.; Crossman, L.C.; Sebaihia, M.; Bentley, S.D.; Cerdeno-Tarraga, A.M.; Thomson, N.R.; Bason, N.; Quail, M.A.; Sharp, S.; et al. The genome of Burkholderia cenocepacia J2315, an epidemic pathogen of Cystic Fibrosis patients. J. Bacteriol. 2009, 191, 261-277. [CrossRef]

44. Spencer, H.K.; Spitznogle, S.L.; Borjan, J.; Aitken, S.L. An Overview of the Treatment of Less Common Non-Lactose Fermenting Gram Negative Bacteria. Pharmacother. J. Hum. Pharmacol. Drug Ther. 2020. accepted. [CrossRef]

45. Pradenas, G.; Myers, J.; Torres, A. Characterization of the Burkholderia cenocepacia TonB Mutant as a Potential Live Attenuated Vaccine. Vaccines 2017, 5, 33. [CrossRef]

46. Musson, J.A.; Reynolds, C.J.; Rinchai, D.; Nithichanon, A.; Khaenam, P.; Favry, E.; Spink, N.; Chu, K.K.Y.; De Soyza, A.; Bancroft, G.J.; et al. CD4 + T Cell Epitopes of FliC Conserved between Strains of Burkholderia: Implications for Vaccines against Melioidosis and Cepacia Complex in Cystic Fibrosis. J. Immunol. 2014, 193, 6041-6049. [CrossRef]

47. Sousa, S.A.; Feliciano, J.R.; Grilo, A.M.; Leitão, J.H. Bioinformatics: A Molecular Microbiologist's Perspective. Curr. Bioinform. 2014, 9, 8-17. [CrossRef]

48. Liu, H.; Ibrahim, M.; Qiu, H.; Kausar, S.; Ilyas, M.; Cui, Z.; Hussain, A.; Li, B.; Waheed, A.; Zhu, B.; et al. Protein Profiling Analyses of the Outer Membrane of Burkholderia cenocepacia Reveal a Niche-Specific Proteome. Microb. Ecol. 2015, 69, 75-83. [CrossRef] [PubMed]

49. Wolden, R.; Pain, M.; Karlsson, R.; Karlsson, A.; Aarag Fredheim, E.G.; Cavanagh, J.P. Identification of surface proteins in a clinical Staphylococcus haemolyticus isolate by bacterial surface shaving. BMC Microbiol. 2020, 20, 80. [CrossRef] [PubMed]

50. Solis, N.; Cordwell, S.J. Cell shaving and False-Positive control strategies coupled to novel statistical tools to profile Gram-Positive bacterial surface proteomes. In Methods in Molecular Biology; Humana Press Inc: New York, NY, USA, 2016; Volume 1440, pp. 47-55.

51. Henderson, B.; Martin, A. Bacterial virulence in the moonlight: Multitasking bacterial moonlighting proteins are virulence determinants in infectious disease. Infect. Immun. 2011, 79, 3476-3491. [CrossRef] [PubMed]

52. Pore, D.; Chakrabarti, M.K. Outer membrane protein A (OmpA) from Shigella flexneri 2a: A promising subunit vaccine candidate. Vaccine 2013, 31, 3644-3650. [CrossRef] [PubMed]

53. Confer, A.W.; Ayalew, S. The OmpA family of proteins: Roles in bacterial pathogenesis and immunity. Vet. Microbiol. 2013, 163, 207-222. [CrossRef] [PubMed] 
54. Darwin, A.J. Stress relief during host infection: The phage shock protein response supports bacterial virulence in various ways. PLoS Pathog. 2013, 9, e1003388. [CrossRef]

55. Southern, S.J.; Male, A.; Milne, T.; Sarkar-Tyson, M.; Tavassoli, A.; Oyston, P.C.F. Evaluating the role of phage-shock protein A in Burkholderia pseudomallei. Microbiology 2015, 161, 2192-2203. [CrossRef]

(C) 2020 by the authors. Licensee MDPI, Basel, Switzerland. This article is an open access article distributed under the terms and conditions of the Creative Commons Attribution (CC BY) license (http://creativecommons.org/licenses/by/4.0/). 